\title{
Landscape Diversity and the Directions of Its Protection in Poland Illustrated with an Example of Wielkopolskie Voivodeship
}

\author{
Sylwia Bródka, Marta Kubacka * (1) and Andrzej Macias
}

Landscape Ecology Research Unit, Adam Mickiewicz University, 61-712 Poznań, Poland; brodka@amu.edu.pl (S.B.); macias@amu.edu.pl (A.M.)

* Correspondence: marta.kubacka@amu.edu.pl

Citation: Bródka, S.; Kubacka, M.; Macias, A. Landscape Diversity and the Directions of Its Protection in Poland Illustrated with an Example of Wielkopolskie Voivodeship. Sustainability 2021, 13, 13812. https:/ / doi.org/10.3390/su132413812

Academic Editors: Piotr Krajewski and Iga Solecka

Received: 3 October 2021

Accepted: 10 December 2021

Published: 14 December 2021

Publisher's Note: MDPI stays neutral with regard to jurisdictional claims in published maps and institutional affiliations.

Copyright: (c) 2021 by the authors. Licensee MDPI, Basel, Switzerland. This article is an open access article distributed under the terms and conditions of the Creative Commons Attribution (CC BY) license (https:// creativecommons.org/licenses/by/ $4.0 /)$.
Abstract: As part of the implementation of the provisions of the European Landscape Convention, a landscape audit of the provinces has been underway in Poland for a few years. The main objectives of the audit are the delimitation of landscape units, assessment of their values, and identification of the priority of landscapes to be protected. This study presents the results of research on the landscape division of the Wielkopolskie voivodeship and a geostatistical analysis of the differentiation of ecological units. With reference to legal regulations in force in Poland, the landscape diversity of the province was characterized using two divisions: geophysical regionalization and landscape typology. In the case of regional division, the meso- and microregions of physical and geographical rank are referenced. The proposed microregional division is the first example in Poland of such a detailed landscape analysis completed for the area of the voivodeship. In the case of typological division, the study conducted in cooperation with the Wielkopolska Bureau of Spatial Planning in Poznań was used. The statistical analysis included metrics to quantitatively characterize landscape composition, including the landscape division index (DIVISION), Shannon's diversity index (SHDI), and Simpson's diversity index (SIDI). The results of the study were then compared with the distribution of areas associated with different forms of landscape protection such as national parks, landscape parks, and protected landscape areas. The applied methodology and the results obtained indicate the important role of physical and geographical microregions in the complex analyses of landscape diversity and their broad application in procedures connected with landscape planning and environmental protection.

Keywords: diversity; physical and geographical regions; landscape units; landscape classification; environmental protection and planning

\section{Introduction}

In a general sense, diversity refers to the material structure in a particular system, understood as the abundance of the types of components and the number of components in the system, as well as their proportions to each other, e.g., in the gene pool, species, cultural groups, institutions, etc. It also includes functional diversity, which is seen as the main source of possible reactions of the system to changes. Diversity in complex social and ecological systems may involve components of both an animate and inanimate nature, social groups, business entities or institutions, and different forms of anthropogenic land investment [1-4].

The variability in the abiotic components of the natural environment is referred to as geodiversity and is related to the variability in geological and geomorphological objects, water, and soil cover, and how they are spatially organized [5-8]. Some authors recognize that the term also applies to processes that are responsible for creating abiotic components and building relationships between them [9-11]. The biotic aspect of diversity means, in turn, the diversity of biogeographical units; the typological diversity of natural habitats and 
ecosystems; and the species diversity of fungi, plants, and animals [2,12-17]. Biodiversity is studied at different levels of its organization: genetic, species, or ecosystem [18-27].

Geo and biodiversity are treated as subsets of a methodologically more complex model of landscape diversity in which the anthropogenic factor plays an important role [28,29]. Specific systems of abiotic elements and living organisms and the processes connecting them create a framework of various forms of human activity, which is expressed, in part, by the nature of land cover and land use. Its spatial structure, expressed by the presence of landscape units that form a specific mosaic in the landscape, is directly related to the problem of studying the diversity of the landscape.

In Poland, analyses of landscape and spatial variability of its elements have been conducted for many years within the framework of two main methodological approaches related to physical and geographical regionalization and landscape typology [30]. The standards of physical and geographical regionalization for the area of the whole country were proposed by Kondracki in the second half of the 20th century. Kondracki's first publications included an outline of the classification concept of regional units, including the criteria and research methods [31,32]. The aim was to propose a hierarchical arrangement of regional units in which a specific set of delimitation criteria could be selected for each level of division. In subsequent works, Kondracki $[33,34]$ modified his division and provided its most up-to-date version, adjusted to modern methods and data sources [35]. The developed regionalization assumptions became the basis for more detailed studies carried out for different areas of the country [36-43]. Simultaneously, work was conducted on the typology of Polish landscapes at different spatial scales. The methodological basis for such divisions includes works by Ostaszewska [44], Solon [45,46], Degórski [47], Chmielewski [48,49], Myga-Piatek [50], Chmielewski et al. [51], and Macias and Bródka [52]. Until the beginning of the 20th century, the analyses of landscape structure were dominated by approaches based on natural parameters defining the nature and functioning of landscape units, considering the geological structure, relief, soil, land cover, and vegetation $[53,54]$. In recent years, landscape classifications in Poland have increasingly considered criteria relating to the degree of anthropization of the environment and the utility functions of the landscape, which are usually features representing different forms of human impact on natural elements, e.g., land use and its dynamics, methods of environmental management, spatial arrangements of agricultural fields and rural settlements, elements of cultural heritage, and physiognomic properties of the landscape related to human impact [55-59].

An integrated approach to the study of landscape diversity, which considers both the natural and cultural context of the issue, creates favorable conditions for taking practical actions to protect landscape values. In Poland, nature protection implemented in the form of different categories of protected areas, such as national parks, nature reserves, landscape parks, areas of protected landscape, and natural and landscape complexes has so far directly impacted the preservation of landscape diversity. The aforementioned areas constitute the national system of nature protection, which are often additionally protected by the Natura 2000 network. At the same time, these areas, where the main objective of landscape protection is directly embedded in their legal status, are the focus of the main protection activities. The work on landscape audits carried out in recent years significantly expanded the possibilities for effective action in the field of landscape management. These actions are the result of legislative actions which contributed to the enactment of legal regulations governing landscape protection in a more comprehensive and orderly manner in response to the ineffectiveness of existing solutions in this scope of the problem (cf. Act of 24 April 2015 on amending certain laws in connection with the strengthening of landscape protection tools, Journal of Laws of 2015, item 774). At the same time, they systematized the approach to the delimitation of landscape units; the assessment of their natural, cultural, and physiognomic values; and the planning of protection directions (cf. Regulation of the Council of Ministers of 11 January 2019 on the preparation of landscape audits, Journal of Laws of 2019, item 394). Notably, the landscape typology proposed in the audit refers to the recommendations of the European Landscape Convention composed in 
Florence on 20 October 2000 (Journal of Laws No. 14, item 98). The effect of the landscape audit is the determination of priority landscapes considered particularly valuable from the point of view of landscape values. Within the scope of priority landscapes, spatial planning and economic activities are subject to significant limitations set out in the form of detailed recommendations in strategic documents at the local level.

The main aim of this study was to demonstrate the role of landscape divisions and classification in the analysis of landscape, as well as to assess the scope of landscape diversity protection on the scale of the Wielkopolskie Voivodeship. The main aim of the study was the investigation of several specific research issues:

1. Discussing of the essence of the landscape division of the Wielkopolskie voivodeship in the system of physical and geographical regions and landscape types;

2. Characterizing the spatial differentiation of landscape units (regional and typological) in the context of selected landscape features;

3. Comparatively analyzing both landscape divisions due to their role in mapping the diversity of the landscape on the scale of the voivodeship with the use of selected landscape metrics;

4. Assessing the importance of current forms of landscape protection for the preservation of its diversity, considering the rank and function of protected areas.

The study used prior authors' division of the Wielkopolskie voivodeship into physical and geographical regions [43] and the typology of landscapes of the Wielkopolskie voivodeship prepared in cooperation with the Wielkopolska Bureau of Spatial Planning. A detailed evaluation of the differentiation of landscape types was carried out with respect to mesoand microregions. The adopted methodological approach is consistent with the assumptions of the landscape audit, in which physical and geographical regions are treated as basic operational units for landscape structure studies at the scale of the voivodeship. Notably, in accordance with the adopted methodology, physical and geographical regions reflect the diversity of features connected with geo and biodiversity to a larger extent (genetic types of relief, surface geological structure and soil, and types of potential vegetation communities), whereas landscape types focus on anthropogenic elements and physiognomic properties of the landscape (land cover and land use, morphometric types of relief, etc.).

\section{Materials and Methods}

\subsection{Study Area}

In terms of the structure of the division of Wielkopolskie in detail, it is situated within the boundaries of the Central European Plain province. The northern part of the voivodship is situated in the South Baltic Lakeland subprovince, which includes six macroregions. The southern part of the voivodship lies in the Central Polish Plain subprovince (318), which includes three macroregions. A small, southernmost fragment belongs to one macroregion. None of the macroregions are located entirely within the borders of the Wielkopolskie voivodeship. Of 42 mesoregions, only 10 are located entirely in the area in question.

The Wielkopolskie voivodeship is situated in the central-western part of Poland and occupies an area of $29.827 \mathrm{~km}^{2}$ with a population of almost 3.5 million inhabitants (Figure 1). It is ranked second of the voivodeships in Poland in terms of area and third in terms of population. The topography is varied and strongly connected with the prior activity of ice sheets. The study area is dominated by vast flat moraine uplands of the Vistula River and Central Poland glaciations. In the Wielkopolskie voivodeship, zonal soils dominate: luvisols; brown, rusty, and podzolic soils. Other soil types are found in small compact areas (e.g., muck and peat soils and alluvial soils, developed in river valleys). 


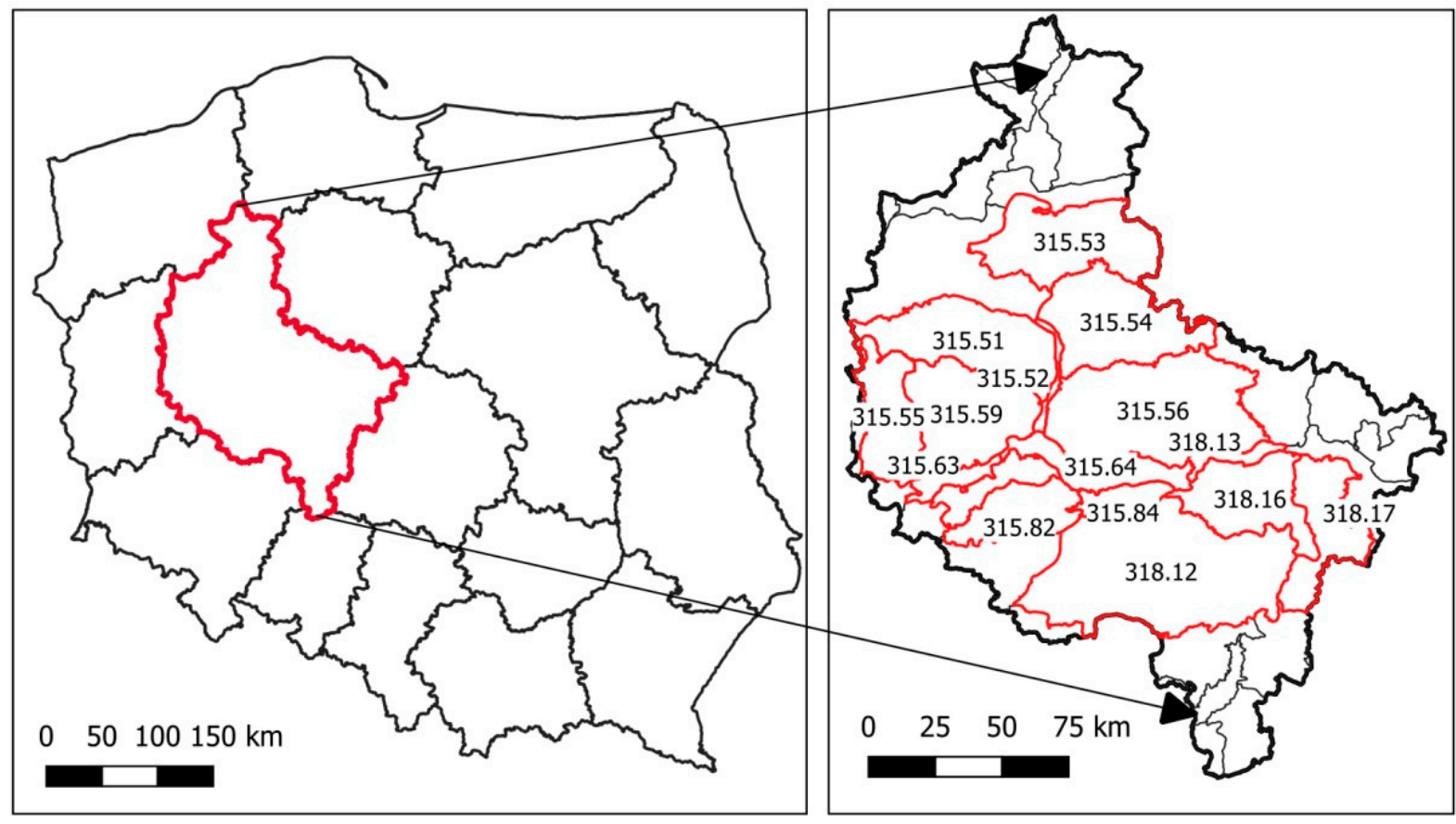

Legend

selected mesoregions border of voivodeships

Figure 1. The study area and its division into mesoregions as the basic units of analysis.

In terms of potential plant communities in the Wielkopolskie voivodeship, there are areas of Central European oak-hornbeam of Silesian-Wielkopolska type (Galio-Carpinetum) that dominate, and, to a lesser extent, areas of continental mixed pine and oak forests (Pino-Quercetum). Most of the oak-hornbeam habitat, due to good soils, has been converted to farmland. Currently, pine is the dominating species, growing in habitats of fresh mixed coniferous forest and fresh coniferous forest.

For detailed analyses, landscape units located in two zones with different geneses of natural conditions were selected. The northern and central parts of the voivodship are connected with the Vistula glaciation, which resulted in a well-developed, young glacial landscape with numerous lakes, whereas the southern part belongs to the Warta and Odra river glaciations (Central Poland glaciations) and is characterized by the presence of a strongly transformed and old glacial landscape. The first zone includes the Wielkopolskie and Leszno Lakeland and the Warta-Odra Proglacial Valley. A wide strip of the South Wielkopolska Plain is connected with the second zone. Detailed analyses were performed on the mesoregions that are located entirely or predominantly within the area of the Wielkopolskie voivodship (Figure 1). There are a total of 16 units, six of which are slightly outside the study area boundaries. Most of the selected mesoregions (10 units) belong to the lake district zone and cover an area of 1266,000 ha, which constitutes over $42 \%$ of the voivodship area (Wielkopolska and Leszno Lakelands). The second group consists of two mesoregions connected with the depression of the Warta and Odra Proglacial Valley, which cover an area of $8,496,000 \mathrm{~m}^{2} .(2.8 \%)$. The third group includes four units situated within the range of the South Wielkopolska Plain zone (21.6\%) (Table 1). 
Table 1. Units selected for landscape diversity analysis in the Wielkopolskie voivodeship.

\begin{tabular}{|c|c|c|c|c|}
\hline \multirow{2}{*}{$\begin{array}{l}\text { Code and Name of the } \\
\text { Region and Its Location on } \\
\text { the Macroregions }\end{array}$} & \multirow[t]{2}{*}{ Area [ha] } & \multirow{2}{*}{$\begin{array}{l}\text { Number of } \\
\text { Microregions }\end{array}$} & \multicolumn{2}{|c|}{$\begin{array}{c}\text { Location of the Mesoregion on the Borders of } \\
\text { the Wielkopolska Voivodeship }\end{array}$} \\
\hline & & & Entire & Partially \\
\hline \multicolumn{5}{|c|}{ MACROREGION: 315.5. Wielkopolska Lakelands } \\
\hline 315.50 Nowy Tomyśl Plain & $97,683,0$ & 6 & & $X$ \\
\hline 315.51 Poznań Lakeland & $183,738,7$ & 17 & & $x$ \\
\hline $\begin{array}{l}315.52 \text { Poznań Gap of the } \\
\text { Warta River }\end{array}$ & $10,766,1$ & 3 & $x$ & \\
\hline 315.53 Chodzieskie Lakeland & $211,726,8$ & 10 & & $\mathrm{X}$ \\
\hline 315.54 Gniezno Lakeland & $185,761,9$ & 10 & & $X$ \\
\hline 315.56 Września Plain & $269,031,6$ & 11 & $x$ & \\
\hline 315.59 Grodzisk Heights & $151,350,5$ & 7 & $X$ & \\
\hline \multicolumn{5}{|c|}{ MACROREGION: 315.6. Warta-Odra Proglacial Valley } \\
\hline $\begin{array}{l}315.63 \text { Middle Obra River } \\
\text { Valley }\end{array}$ & $23,097,6$ & - & $X$ & \\
\hline 315.64 Śrem Basin & $61,861,4$ & 3 & $x$ & \\
\hline \multicolumn{5}{|c|}{ MACROREGION: 315.8. Leszczyńskie Lakelands } \\
\hline 315.82 Krzywiń Lakeland & $79,588,9$ & 4 & $x$ & \\
\hline 315.83 Kościan Plain & $46,095,0$ & 2 & $X$ & \\
\hline 315.84 Żerków Heights & $30,557,0$ & 2 & $X$ & \\
\hline \multicolumn{5}{|c|}{ MACROREGION: 318.1-2. South Wielkopolska Plain } \\
\hline 318.12 Kalisz Heights & $378,284,1$ & 14 & & $X$ \\
\hline 318.13 Konin Valley & $17,927,6$ & - & $x$ & \\
\hline 318.16 Rychwał Plain & $116,060,2$ & 4 & $x$ & \\
\hline 318.17 Turek Heights & $132,556,9$ & 4 & & $X$ \\
\hline
\end{tabular}

\subsection{Methodology}

Various methods and source materials were used in this research. For the delimitation of regional and typological units, a deductive approach was used, which consisted of dividing the landscape into units of increasingly lower rank, considering an increasing number of criteria and their more precise classifications. In order to determine the physical and geographical microregions, the assumptions of regional division of Poland according to Kondracki [34] were used. The starting point in the analysis of landscape differentiation was the system of physical and geographical mesoregions in Poland [35], within the boundaries of which lower-order units-the rank of microregions-were delimited. The division was achieved on the basis of the analysis of the map of the boundary density, created from the superimposition of thematic layers containing separations characterizing the spatial variability in the analyzed features of the natural environment. The main criteria of microregional division included type and genesis of surface geological formations, genetic types of relief, depth of groundwater occurrence, genetic types of soil, and communities of potential natural vegetation. The first step in the research procedure was to conduct a two-sided buffering of the boundaries of each spatial separation for all analyzed data layers (the width of the buffer was $50 \mathrm{~m}$ from the separation boundary). The overlap between individual buffers was analyzed in a regular grid of $2500 \mathrm{~m}^{2}$. This allowed for modeling the boundaries of microregions according to the arrangement of squares in which the number of overlapping features was the highest. The obtained boundaries of microregions 
in the form of linear objects were then transformed into surface objects. Each of these areas was assigned attribute data in the form of code and name of the microregion, its area, and selected elements of natural characteristics. A detailed description of the research methods and tools used, as well as the characteristics of the physic-geographical division obtained in the Wielkopolskie voivodeship, was provided by Macias et al. [43].

The delimitation of landscape types in the Wielkopolskie voivodeship was based on the guidelines of the landscape audit (cf. Regulation of the Council of Ministers of 11 January 2019 on landscape audit, Journal of Laws of 2019, item 394). The starting point was the division into physical and geographical mesoregions, within the boundaries of which the landscape background was then analyzed, which means the type of land cover or land use that superficially dominated within the region, and that constituted the surroundings of most of the other spatial elements of the landscape. The presented landscape division considers two levels of typological classification. The first is connected with increasing levels of human pressure and includes three groups: natural landscapes, extensively used by humans (group A); natural and cultural landscapes, shaped as a result of the interaction of natural and anthropogenic processes (group B); and cultural landscapes, whose structure and functions are fully shaped by human activity (group C). The second level of classification is related to the analysis of the dominant forms of land cover, which resulted in 13 types of landscapes: surface water, forestless (xerothermic grasslands, heathlands and inland dunes), marshy meadows, forests, rural, mosaic, suburban and settlement, urban, metropolitan, water-economic, industrial, mining, and communication areas. These identified units were additionally differentiated in terms of morphometric features of terrain relief, considering four types of landscapes: flat, undulating, hilly, and valley. The morphometric types of relief were treated as a criterion supplementing the landscape division, especially in the case of vast rural areas, where the diversity of landform features affects the physiognomic values of the landscape and how they are perceived.

Quantitative analysis methods based on landscape metrics were chosen to assess the composition and spatial configuration between two selected landscape divisions: mesoregions and microregions. Measuring diversity was explored across landscape ecology with various metrics, and for our analysis, we chose only four metrics (Table 2) that mainly focus on assessing the degree of landscape diversity. The metrics were calculated using the landscape structure analysis program FRAGSTATS [60,61]. This software is recommended for use with raster datasets and is the most common program used to quantitatively analyze the correlations between landscape patterns and ecological processes [62-67]. The landscape division index (DIVISION) is based on the cumulative patch area distribution and is interpreted as the probability that two randomly chosen pixels in the landscape are not situated in the same patch [68]. The last two tested metrics were Shannon's diversity index (SHDI) and Simpson's diversity index (SIDI). These diversity indices were initially developed as a method to calculate the richness of a particular species in an area, and are still widely used for that purpose [69]. Almost all diversity indexes measure the same type of statistical information and generate redundancy, but our main goal in using landscape metrics was to identify the differences in diversity between mesoregions and microregions. It is also obvious that landscape metrics are relatively sensitive to spatial or temporal scales, with the value significantly increasing with the scale (known as scaling effects) [70,71]. All GIS and statistical analyses were performed with use of the ArcMap and R software ( $R$ version 3.6.3). In addition, to determine the level of variation in the study variables, their statistical significance was determined. Figures 3 and 5 provide the detailed averages of the computed metrics including the basic components of a box plot graph that provides information regarding the location, dispersion, and shape of the data distribution. 
Table 2. Selected landscape metrics [60].

\begin{tabular}{|c|c|c|c|}
\hline Metric Name & Indicator Abbreviation & Formula & Units \\
\hline Landscape Division Index & DIVISION & $\begin{array}{c}\text { DIVISION }=\left[1-\sum_{\mathrm{j}=1}^{\mathrm{n}}\left({\frac{\mathrm{a}_{\mathrm{ij}}}{\mathrm{A}}}^{2}\right)\right] \\
\mathrm{a}_{\mathrm{ij}}=\text { area }\left(\mathrm{m}^{2}\right) \text { of patch } \mathrm{ij} \\
\mathrm{A}=\text { total landscape area }\left(\mathrm{m}^{2}\right)\end{array}$ & $\begin{array}{c}\text { Proportion } \\
0 \leq \text { DIVISION < } 1\end{array}$ \\
\hline Shannon's Diversity Index & SHDI & $\begin{array}{l}\text { SHDI }=-\sum_{i=1}^{m}\left(P_{i}^{\circ} \ln P_{i}\right) \\
P_{i}=\text { proportion of the landscape } \\
\text { occupied by patch type (class) } i \text {. }\end{array}$ & $\begin{array}{c}\text { none } \\
\text { SHDI } \geq 0 \text {, without limit }\end{array}$ \\
\hline Simpson's Diversity Index & SIDI & $\mathrm{SIDI}=1-\sum_{\mathrm{i}=1}^{\mathrm{m}} \mathrm{P}_{\mathrm{i}}^{2}$ & $\begin{array}{c}\text { none } \\
0 \leq \text { SIDI }<1\end{array}$ \\
\hline Patch Richness & PR & $\begin{array}{c}\mathrm{PR}=\mathrm{m} \\
\mathrm{m}=\text { number of patch types (classes) } \\
\text { present in the landscape }\end{array}$ & $\begin{array}{c}\text { none } \\
P R \geq 1, \text { without limit }\end{array}$ \\
\hline
\end{tabular}

A number of source materials were used in this study, mainly cartographic studies, amongst which digital data were preferred. In the first stage of analyses related to the delimitation of physico-geographical regions and landscape types, the main sources of information included layers of numerical data: a detailed geological map of Poland at a scale of 1:50,000, a geomorphological map of the Wielkopolska-Kujawy Plain at the scale of 1:100,000, a numerical terrain model with a resolution of $50 \mathrm{~m}$, a hydrographic map of Poland on a 1:50,000 scale, a soil and agricultural map of Poland at the scale of 1:100,000, a potential natural vegetation map of Poland at the scale of 1:300,000, a topographic map of Poland at scale 1:50,000, level 2 (VMap Level 2), the CORINE Land Cover database, and a database of topographic objects. Before starting the GIS analyses to separate landscape units, it was necessary to obtain a set of uniform layers of spatial data for each of the delimitation criteria. The following were considered important features of the source materials: the scope of the thematic data, the accuracy, the degree of data coverage of the research areas, and the data type and format. To perform GIS analyses, we saved input data in a vector format, containing surface features of the polygon type (shp). This digital data format was directly preferred when selecting sources for spatial information. This allowed us to avoid the need for time-consuming processing and standardization. Due to the different accuracies of the source materials, some of the data required more detail (e.g., the layer of genetic relief types, which was refined on the basis of the VMap Level 2, the numerical terrain model $(50 \mathrm{~m})$, the detailed geological map of Poland, geomorphological sketches, and aerial photos), whereas others needed generalization (e.g., the numerical terrain model from airborne laser scanning (ALS-LiDAR) with a resolution of $1 \mathrm{~m}$, which was reduced to a resolution of $50 \mathrm{~m}$ ). In the second stage of the research, related to the quantitative analysis of landscape diversity based on landscape metrics, we conducted work on the vector layers (shp) containing a hierarchical division into physical and geographic regions, mesoregions and microregions, and into landscape types and subtypes. In the third stage, concerning the assessment of the scope of landscape diversity protection in the Wielkopolskie voivodeship, we used numerical layers and descriptive data on landscape protection areas (national parks, landscape parks, and protected landscape areas), obtained from the General Directorate for Environmental Protection and statistical data provided by the Central Statistical Office.

\section{Results and Discussion}

\subsection{Analysis of Landscape Diversity in the Wielkopolskie Voivodeship Using Regional and} Typological Division

As a result of the delimitation, 181 microregions were distinguished [43]. In terms of size, microregional units were dominated by those with an area less than $100 \mathrm{~km}^{2}(41.8 \%$ of units) and those with an area between 100.1 and $200 \mathrm{~km}^{2}(41.2 \%)$. The third group consisted of those with an area between 200.1 and $300 \mathrm{~km}^{2}(14 \%)$. The remaining $3 \%$ were 
microregions with an area exceeding $300 \mathrm{~km}^{2}$. The division shows a diversified spatial structure and size of designated units. The differences between the microregions were found to be directly related to their location within two zones: the young glacial landscape covering the northern and central parts of the Wielkopolskie voivodship and the old glacial landscape covering the southern parts. Greater fragmentation and latitudinal arrangement are characteristic features of the microregions located in the young glacial zone. There are 133 microregions ( $73.5 \%$ of units) within its boundaries. They have an average area of $116 \mathrm{~km}^{2}$ and $59 \%$ of them could be characterized by a clearly visible latitudinal pattern. The elongated shape of the microregions is particularly noticeable in the valleys of large rivers such as the Warta and Noteć Rivers. In the second zone, there are 48 microregions (26.5\% of the units), among which the larger ones with an average area of $165 \mathrm{~km}^{2}$ predominate. Of these units, $61 \%$ are characterized by a meridional arrangement.

Regarding the characteristics of microregions, in terms of differentiation of abiotic features of the environment, in the case of genetic types of relief, areas with small differences in relative height associated with the presence of flat or undulating moraine uplands (32\% and $13 \%$ of units, respectively) and outwash plains (19\% of units) prevail. The highest concentration of microregions with the predominance of plains and flat uplands is characteristic of the central and southwestern part of the province (Table 3). Groups of microregions with the predominance of undulating uplands occur in the central and eastern part of the studied area. Conversely, a greater consolidation of microregions with the predominance of relief in the form of middle and high alluvial terraces $(17 \%)$ occurs in the northwestern, southeastern, and central parts. In addition, there are local microregions connected with end moraines, moraine dikes, dune slopes, and long slopes $(10 \%)$ and more elongated units occupied by troughs ( $9 \%$ ).

Table 3. Characteristics of the landscape diversity of the Wielkopolskie voivodeship in the context of selected landscape features.

\begin{tabular}{|c|c|c|c|}
\hline A Feature That & $\begin{array}{l}\text { etermines the Diversity of the } \\
\text { Landscape }\end{array}$ & $\begin{array}{l}\text { Share in the Area of } \\
\text { Voivideship (\%) }\end{array}$ & Selected Landscape Units \\
\hline \multirow{6}{*}{$\begin{array}{l}\text { Genetic types } \\
\text { of relief }\end{array}$} & Outwash plains & $19 \%$ & \multirow{2}{*}{$\begin{array}{l}\text { Grodzisk Heights (315.59); Września Plain (315.56); } \\
\text { Leszno Heights (318.11); Kalisz Heights (318.12) }\end{array}$} \\
\hline & Flat moraine uplands & $32 \%$ & \\
\hline & Undulating moraine uplands & $13 \%$ & $\begin{array}{c}\text { Poznań Lakeland (315.51); Chodzieskie Lakeland } \\
\text { (315.53); } \\
\text { Gniezno Lakeland (315.54) }\end{array}$ \\
\hline & $\begin{array}{l}\text { Middle and high alluvial } \\
\text { terraces }\end{array}$ & $17 \%$ & $\begin{array}{c}\text { Wałcz Lakeland (314.64); Gorzów Basin (315.33); } \\
\text { Poznań Gap of the Warta River (315.52); Śrem Basin } \\
\text { (315.64); Koło Basin (318.14); Rychwał Plain (318.16); } \\
\text { Grabów Basin (318.21) }\end{array}$ \\
\hline & $\begin{array}{l}\text { Moraines, moraine dikes, } \\
\text { dune slopes and long slopes }\end{array}$ & $10 \%$ & - \\
\hline & Troughs & $9 \%$ & - \\
\hline \multirow{4}{*}{$\begin{array}{l}\text { Morphometric } \\
\text { types of relief }\end{array}$} & Plain areas & $60 \%$ & $\begin{array}{c}\text { Grodzisk Heights (315.59); Kościan Plain (315.83); } \\
\text { Leszno Heights (318.11); Kalisz Heights (318.12); } \\
\text { Rychwał Plain (318.16) } 4\end{array}$ \\
\hline & Undulating areas & $26 \%$ & $\begin{array}{c}\text { Poznań Lakeland (315.51); Chodzieskie Lakeland } \\
\text { (315.53); Gniezno Lakeland (315.54) }\end{array}$ \\
\hline & Valley landscapes & $11 \%$ & $\begin{array}{c}\text { Middle Noteć River Valley (315.34); Middle Obra } \\
\text { River Valley (315.63); Śrem Basin (315.64); Konin } \\
\text { Valley (318.13); Koło Basin (318.14) }\end{array}$ \\
\hline & Hilly terrain & $3 \%$ & $\begin{array}{c}\text { Small patches in the Grodzisk Heights (315.59) and } \\
\text { Ostrzeszów Hills (318.46) }\end{array}$ \\
\hline
\end{tabular}


Table 3. Cont.

\begin{tabular}{|c|c|c|c|}
\hline \multicolumn{2}{|c|}{$\begin{array}{l}\text { A Feature That Determines the Diversity of the } \\
\text { Landscape }\end{array}$} & \multirow{2}{*}{$\begin{array}{c}\text { Share in the Area of } \\
\text { Voivideship (\%) } \\
40 \% \\
\end{array}$} & \multirow{2}{*}{$\begin{array}{c}\text { Selected Landscape Units } \\
\text { Poznań Lakeland (315.51); Gniezno Lakeland } \\
\text { (315.54); Września Plain (315.56); Krzywiń Lakeland } \\
\text { (315.82); Leszno Heights (318.11); Kalisz Heights } \\
\text { (318.12) }\end{array}$} \\
\hline $\begin{array}{l}\text { Type of } \\
\text { surficial }\end{array}$ & Boulder clays & & \\
\hline $\begin{array}{l}\text { geological } \\
\text { formations }\end{array}$ & $\begin{array}{l}\text { Fluvioglacial sands and } \\
\text { gravels }\end{array}$ & $30 \%$ & $\begin{array}{l}\text { Nowy Tomyśl Plain (315.50); Turek Heights (318.17); } \\
\text { Milicz Basin (318.34) }\end{array}$ \\
\hline & $\begin{array}{l}\text { Surface formations of fluvial } \\
\text { accumulation (gravels, sands, } \\
\text { silts and clays) }\end{array}$ & $15 \%$ & River valleys \\
\hline \multirow{6}{*}{$\begin{array}{l}\text { Genetic types } \\
\quad \text { of soil }\end{array}$} & Forest soils & $38 \%$ & $\begin{array}{l}\text { Wałcz Plain (314.65); Gwda River Valley (314.68); } \\
\text { Gorzów Basin (315.33) }\end{array}$ \\
\hline & Luvisols & $24 \%$ & $\begin{array}{c}\text { Poznań Lakeland (315.51); Grodzisk Heights } \\
\text { (315.59); Września Plain (315.56) }\end{array}$ \\
\hline & $\begin{array}{l}\text { Soils of different origin } \\
\text { formed from sands and } \\
\text { gravels }\end{array}$ & $21 \%$ & $\begin{array}{c}\text { Rychwał Plain (318.16); Turek Heights (318.17); } \\
\text { Grabów Basin (318.21); Wieruszów Heights (318.24); } \\
\text { Ostrzeszów Hills (318.46) }\end{array}$ \\
\hline & Brown soils & $6 \%$ & Southern Krajna Lakeland (314.74) \\
\hline & Peat and muck soils & $4 \%$ & \multirow{2}{*}{$\begin{array}{l}\text { Middle Noteć River Valley (315.34); Middle Obra } \\
\text { River Valley (315.63); Konin Valley (318.13); Koło } \\
\text { Basin (318.14) }\end{array}$} \\
\hline & Alluvial soils & $3 \%$ & \\
\hline \multirow{3}{*}{$\begin{array}{l}\text { Potential } \\
\text { vegetation } \\
\text { community } \\
\text { types }\end{array}$} & Oak-hornbeam communities & $60 \%$ & $\begin{array}{l}\text { Southern Krajna Lakeland (314.74); Poznań } \\
\text { Lakeland (315.51); Chodzieskie Lakeland (315.53); } \\
\text { Gniezno Lakeland (315.54); Września Plain (315.56); } \\
\text { Grodzisk Heights (315.59); Kalisz Heights (318.12) }\end{array}$ \\
\hline & Pine forests & $28 \%$ & $\begin{array}{c}\text { Gorzów Basin (315.33); Rychwał Plain (318.16); } \\
\text { Grabów Basin (318.21) } \\
\text { Milicz Basin (318.34) }\end{array}$ \\
\hline & Riparian communities & $8 \%$ & Depressions filled with river waters \\
\hline \multirow{5}{*}{$\begin{array}{l}\text { Land cover and } \\
\text { land use classes } \\
\text { types }\end{array}$} & Rural & $52 \%$ & $\begin{array}{l}\text { Września Plain (315.56); Grodzisk Heights (315.59); } \\
\text { Krzywiń Lakeland (315.82); Kościan Plain (315.83); } \\
\text { Kalisz Heights (318.12) }\end{array}$ \\
\hline & Forest & $27 \%$ & $\begin{array}{c}\text { Wałcz Plain (314.65); Gorzów Basin (315.33); Nowy } \\
\text { Tomyśl Plain (315.50) }\end{array}$ \\
\hline & Marshy-meadow & $10 \%$ & $\begin{array}{c}\text { Part of the Gorzów Basin (315.33); Middle Noteć } \\
\text { River Valley (315.34); Middle Obra River Valley } \\
\text { (315.63); } \\
\text { Koło Basin (318.14) }\end{array}$ \\
\hline & Water surface & $2 \%$ & Large rivers and lakes above 100 ha \\
\hline & $\begin{array}{c}\text { Urban, suburban, industry } \\
\text { and mining }\end{array}$ & $6 \%$ & - \\
\hline
\end{tabular}

A similar spatial distribution was observed in the case of groupings of microregions, which are characterized by the predominance of a particular type of surficial geological formation. It especially concerns the most numerous groups of microregions, which show the predominance of boulder clays for as much as $40 \%$ of the units concentrated mainly in the central-eastern and southwestern part of the voivodeship (Table 3). Moreover, microregions with a predominance of fluvioglacial sands and gravels (water-glacial) and fluvial-water-glacial sands and gravels (30\% of units) are grouped mainly in the western and southeastern part of the studied area. A specific type of surface formation is that 
associated with fluvial accumulation (gravels, sands, silts and clays), the majority of which accompanies microregions concentrated along rivers (15\% of units).

In terms of soil genetic types, the most numerous groups include the microregions with forest soils (38\%), which are located mainly along the western border of the voivodeship and in its northern part. The next two groups are microregions with a predominance of luvisols (24\%) and soils of different origins formed from sands and gravels (21\%). They form a mosaic of units in the central and southern parts of the voivodeship, with larger concentrations of luvisols in the west and where soil clusters of various geneses cover the eastern and southern parts of the analyzed area (Table 3). In the northeastern part of the voivodeship, the predominant soil is leached brown soil $(6 \%)$, while in the depressions of the terrain, there are alluvial soils (3\%) and peat and muck soils (4\%).

Considering the differentiation of the potential vegetation community types, the greatest number of microregions are represented by oak-hornbeam communities $(60 \%$ of units) and pine forests ( $28 \%$ ). Oak-hornbeam forests dominate in microregions located in the central and southwest parts of the voivodeship (Table 3). In turn, pine forests are characteristic of microregion clusters located in the northwest and southeast of the voivodeship. In the depressions filled with river waters, there are riparian communities ( $8 \%$ of the microregions).

The Wielkopolskie voivodeship is characterized by considerable diversification of landscape physiognomic features, resulting from spatial variability in land cover and land use forms and morphometric features of relief. In total, within the boundaries of Wielkopolskie voivodeship, 2486 landscape units were distinguished, which represent 52 different types. In terms of the area covered, rural landscapes prevail, accounting for $52 \%$ of the voivodeship area (Table 3). Their large area and low perforation associated with the presence of local areas of other uses (mainly forest, urban, and suburban) are characteristic features of patches of the rural landscape. A lower share is represented by dense areas of forest landscapes $(27 \%)$, the accumulation of which is noticeable along the northern and western borders of the voivodeship. Marshy-meadow landscapes occupy $10 \%$ of the study area; they mainly accompany the Noteć valley in the north of the voivodeship and fragmentarily in the Warta River valley (the section between Koło and Konin) and the Obra River valley (the section between Mosina and Solec) in the southern part of the voivodeship. Units with a predominance of surface water (large rivers and lakes above 100 ha in area) account for $2 \%$, whereas those related to suburban and settlement as well as urban and metropolitan landscapes cover a total of $6 \%$.

Concerning morphometric types of relief, plain areas prevail (60\%), which form vast and compact areas located mainly in the central and southern parts of the Wielkopolskie voivodship (Table 3). Undulating areas are located in the north of the studied area (26\%) and are mainly connected with the lake lands. At the voivodeship scale, the valley landscapes (11\%) form two broad zones arranged latitudinally and filled with the water of the main rivers: the Noteć, Warta, and Obra Rivers. Small patches of hilly terrain are present in the west of the region near Grodzisk Wielkopolski (3\%) and in its southern part near Ostrzeszów.

The analysis of the values of the metrics describing the diversity of landscape types within the borders of the meso- and microregions selected for the analysis revealed a tendency related to the decrease in the diversity of these elements with the transition to units of lower rank. This is also confirmed by the calculated values of statistical significance $(p$-value $<0.05)$. The landscape features in the microregions, therefore, have a higher internal consistency than in the mesoregions, and much better represent the actual spatial variability of the studied attributes. Notabl, for the morphometric types of landforms are the mapping of natural features, their internal consistency being much higher than for land use types that depict unnatural features associated with the anthropogenic transformation of the landscape (Table 4). We observed regularity in all indices, but the greatest difference between meso- and microregions was observed in relation to the Shannon's diversity index 
(SHDI), which amounts to 0.1799 for relief, whereas for land use, it reaches a value of 0.1501 .

Table 4. Average values of the calculated metrics.

\begin{tabular}{|c|c|c|c|c|c|c|c|c|}
\hline \multirow{2}{*}{$\begin{array}{c}\text { Landscape } \\
\text { Metric }\end{array}$} & \multicolumn{4}{|c|}{ Types of Land Use/Land Cover } & \multicolumn{4}{|c|}{ Types of Relief } \\
\hline & DIVISION & SHDI & SIDI & PR & DIVISION & SHDI & SIDI & PR \\
\hline Tested area & 0.8854 & 1.0587 & 0.5032 & - & 0.8883 & 0.9457 & 0.5260 & - \\
\hline Mesoregions & 0.6408 & 0.9364 & 0.4746 & 7.8 & 0.4351 & 0.6050 & 0.3440 & 3.6 \\
\hline Microregions & 0.5050 & 0.7863 & 0.4158 & 5.6 & 0.2811 & 0.4251 & 0.2495 & 2.7 \\
\hline$p$-value & \multicolumn{8}{|c|}{$<0.05$} \\
\hline
\end{tabular}

In terms of land cover and land use classes, the landscape division index (DIVISION) measure for the entire study area is 0.8854 (Table 4 ). The average number of separate land cover and land use classes (patch richness) by mesoregion is 7.8, and by microregion, only 5.6 (Table 4 and Figure 2A,B. In the case of mesoregions within valley areas, the dominant landscape types are surface water $(1.5 \%)$ and marshy-meadow areas (1.3\%). In areas outside the reach of the valleys (plains and uplands), rural landscapes prevail (97.2\%). Forest and urban landscapes are not a dominant element in any of the studied mesoregions and thus do not clearly define them (Figure 3).

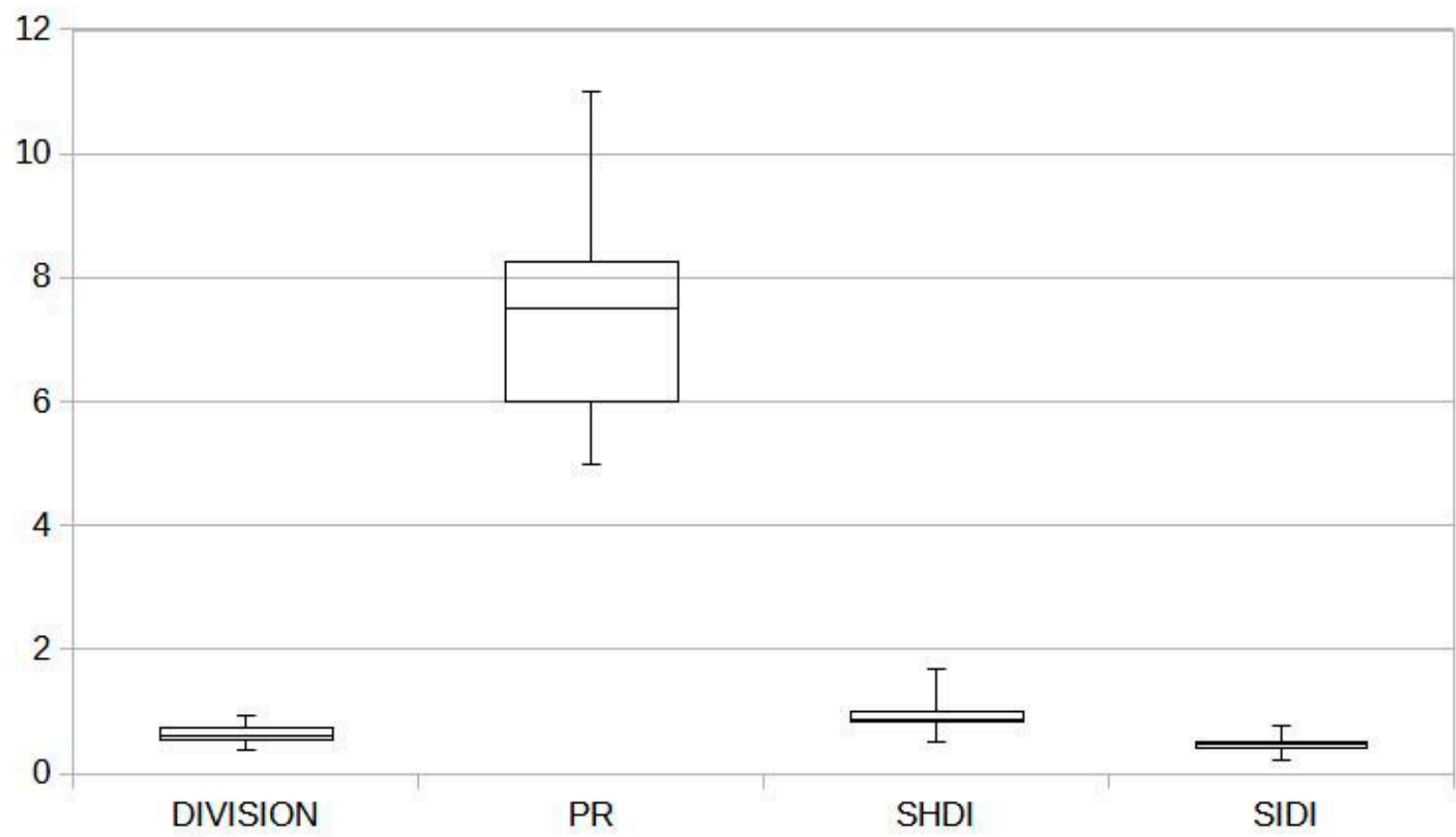

(A)

Figure 2. Cont. 


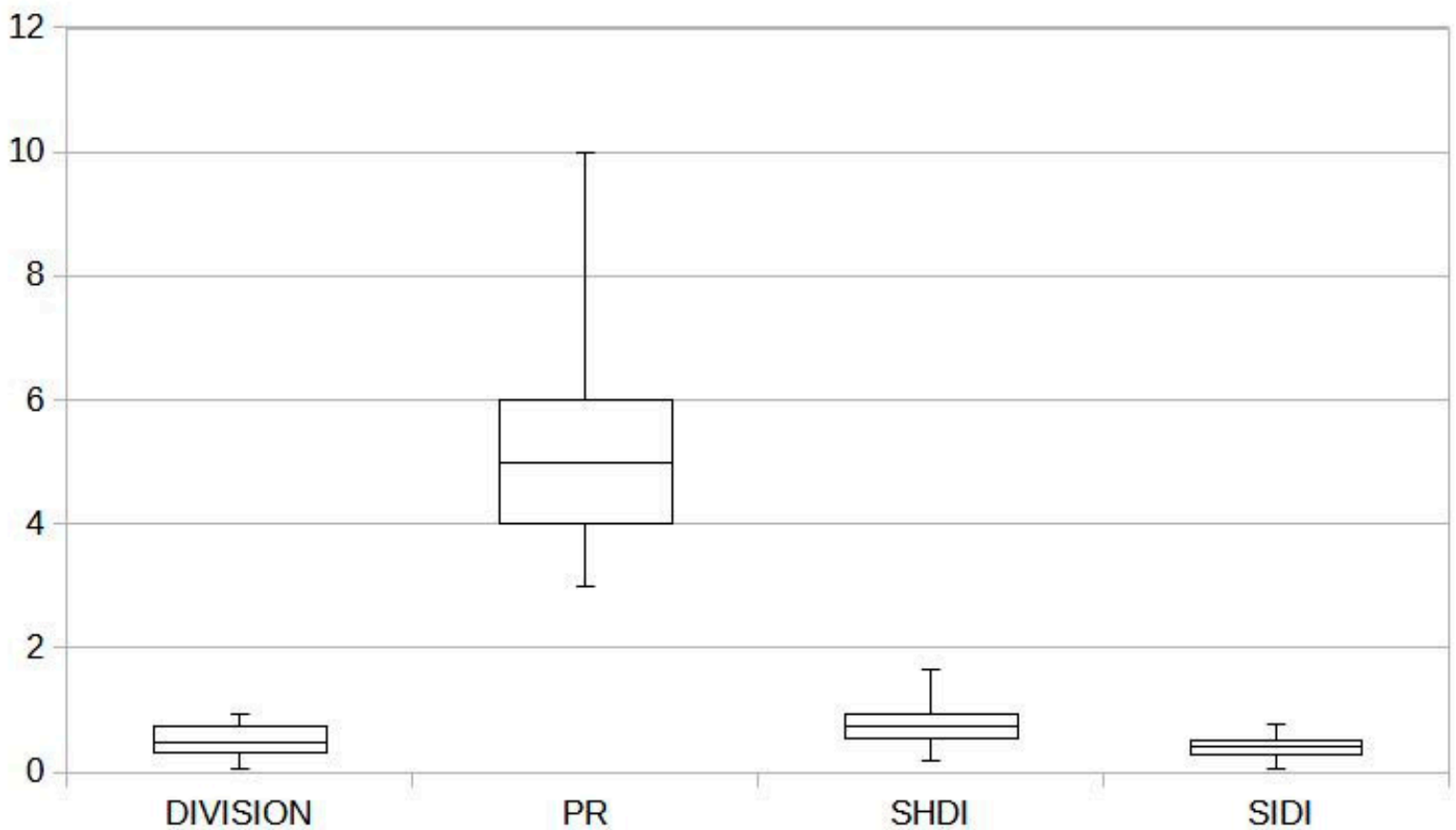

(B)

Figure 2. (A) Measures of landscape differentiation in terms of land cover and land use classes: mesoregions. (B) Measures of landscape differentiation in terms of land cover and land use classes: microregions.

(A)

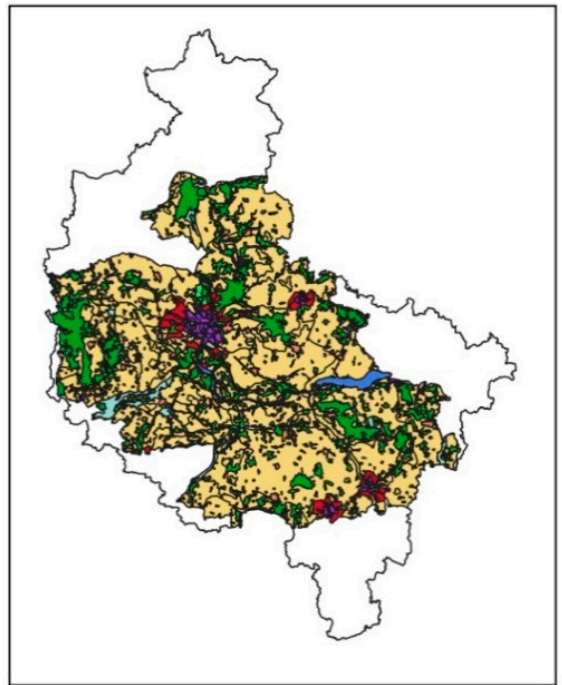

(B)

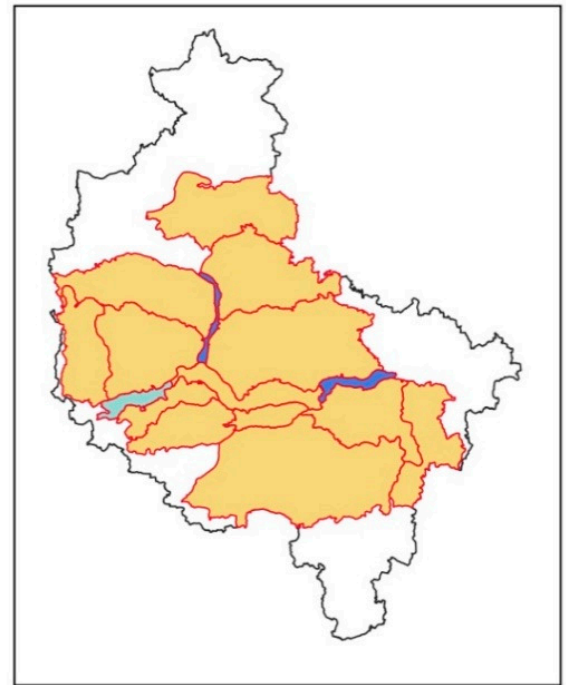

(C)

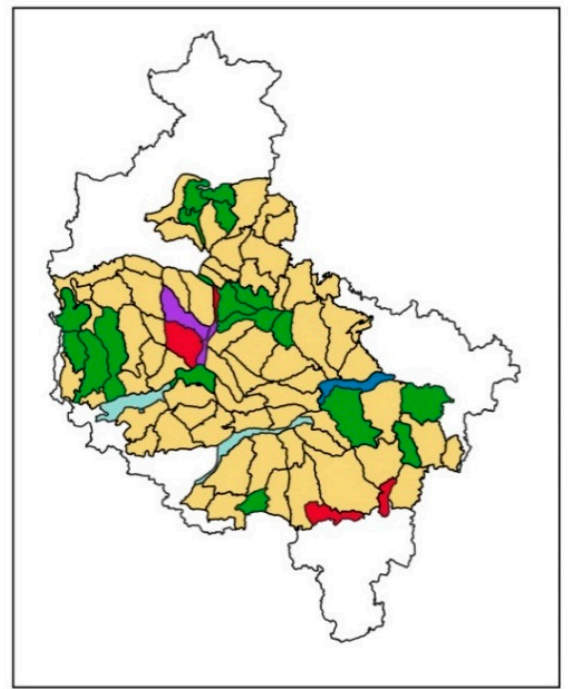

\begin{tabular}{|c|c|}
\hline \multicolumn{2}{|l|}{$\begin{array}{llllll}\text { Legend: } & 0 & 20 & 40 & 60 \mathrm{~km} \\
& & & & \end{array}$} \\
\hline Landscape unit - land use/land cover & $\square$ rural \\
\hline$\square$ communication & suburban \\
\hline$\square$ forest & $\square$ swamp-meadow \\
\hline$\square$ grassland & $\square$ urban \\
\hline$\square$ industry & $\square$ water management \\
\hline metropolitan & $\square$ water surface \\
\hline mining & $\square$ Wielkopolskie voivodeship \\
\hline$\square$ mosaic & $\square$ border of mesoregions \\
\hline & $\square$ border of microregions \\
\hline
\end{tabular}

Figure 3. Differentiation of landscape in terms of land cover and land use classes (A) and with the division into dominant land cover types within the boundaries of physical and geographical regions: mesoregions (B) and microregions (C). 
The microregional breakdown is dominated by rural landscapes (74.6\%). Forest landscapes are prominent and predominate in up to $18 \%$ of the microregions (Figure 3, section C). At the level of microregions, it is also possible to identify units where marshymeadow landscapes prevail $(2.3 \%)$, as well as the suburban and settlement area $(2.8 \%)$, and metropolitan landscapes (1.5\%). The results obtained showed a high correspondence between the spatial variability in land cover and land use types and the dominant landscape types identified on that basis in individual microregions (Figure 3, section A and C). In the case of mesoregions, the relationship described is much weaker (Figure 3, section A and B).

The largest discrepancies in the representation of landscape diversity between mesoand microregions can be observed in the central part of the voivodeship within the boundaries of the Wielkopolskie Lakeland (a zone of young glacial origin). The mesoregions in which this difference is significant include the Nowy Tomyśl Plain, where as many as five out of six microregions represent a different type of dominant landscape than the unit of a higher rank. A similar situation can also be observed in the case of the Chodzież Lakeland (4 out of 10 microregions represent a different type of dominant landscape than the unit of higher rank).

For morphometric relief type, the measure of landscape diversity value (DIVISION) for the entire study area is 0.8883 (Table 4 ) and is close to the value for land cover and land use classes (0.8854). In the division into mesoregions, plains (69.4\%) and undulating landscapes $(24.5 \%)$ are the dominant relief types. Similar values can be obtained by analyzing the dominant features in the micro-regional breakdown (66.8\% and $25 \%$, respectively; Figure 4 ). In contrast, valley areas predominate in $6 \%$ of both region types. Notably, in the case of microregions, hilly areas are additionally visible as a dominant landscape type in $2 \%$ of these units.

(A)

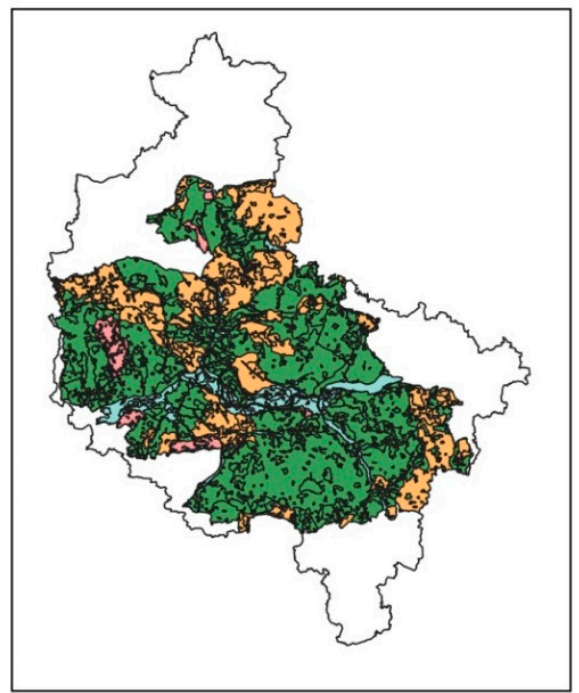

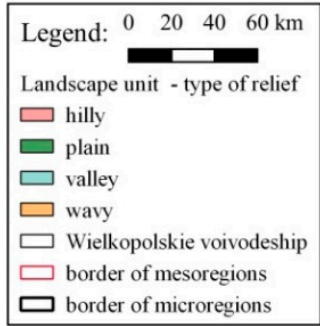

(B)

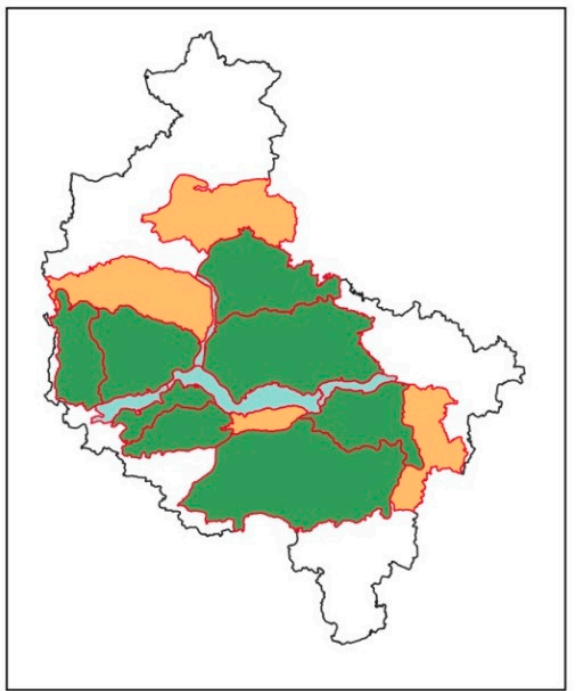

(C)

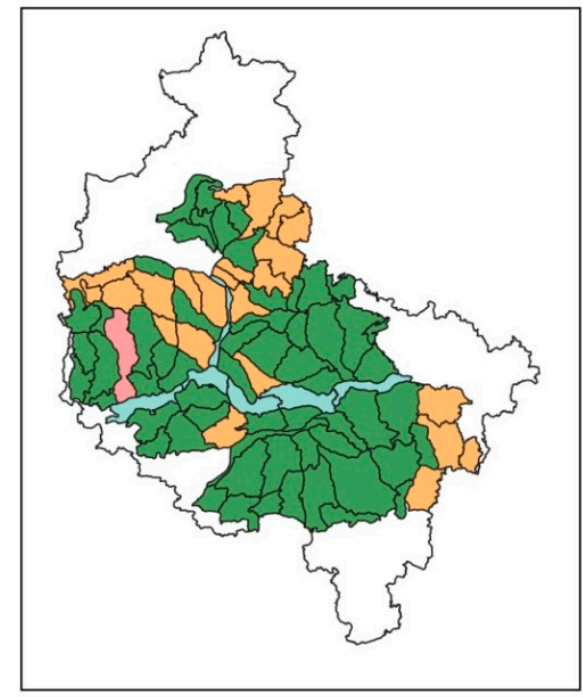

Figure 4. Differentiation of landscape in terms of relief with the division into dominant relief types (A) within the boundaries of physical and geographical regions: mesoregions (B) and microregions (C). 
The described differences in the relief types identified at the meso- and microregional levels indicate a high coherence of this landscape feature in the microregional units (Table 4). The average number of separated relief classes (patch richness) by mesoregion is 3.6 and by microregion, only 2.7 (Table 4 and Figure 5A,B). The homogeneity of relief features in the microregions is confirmed by the values of all landscape diversity metrics (Table 4), i.e., the landscape division index (DIVISION), Shannon's diversity index (SHDI), and Simpson's diversity index (SIDI). The values of these indices are clearly lower than the values obtained for the mesoregional division (Figure 5A,B). In addition, they show high statistical significance ( $p$ value $<0.05$ ) in each parameter analyzed: mean value, median, maximum value, minimum value, and first and third quarters.

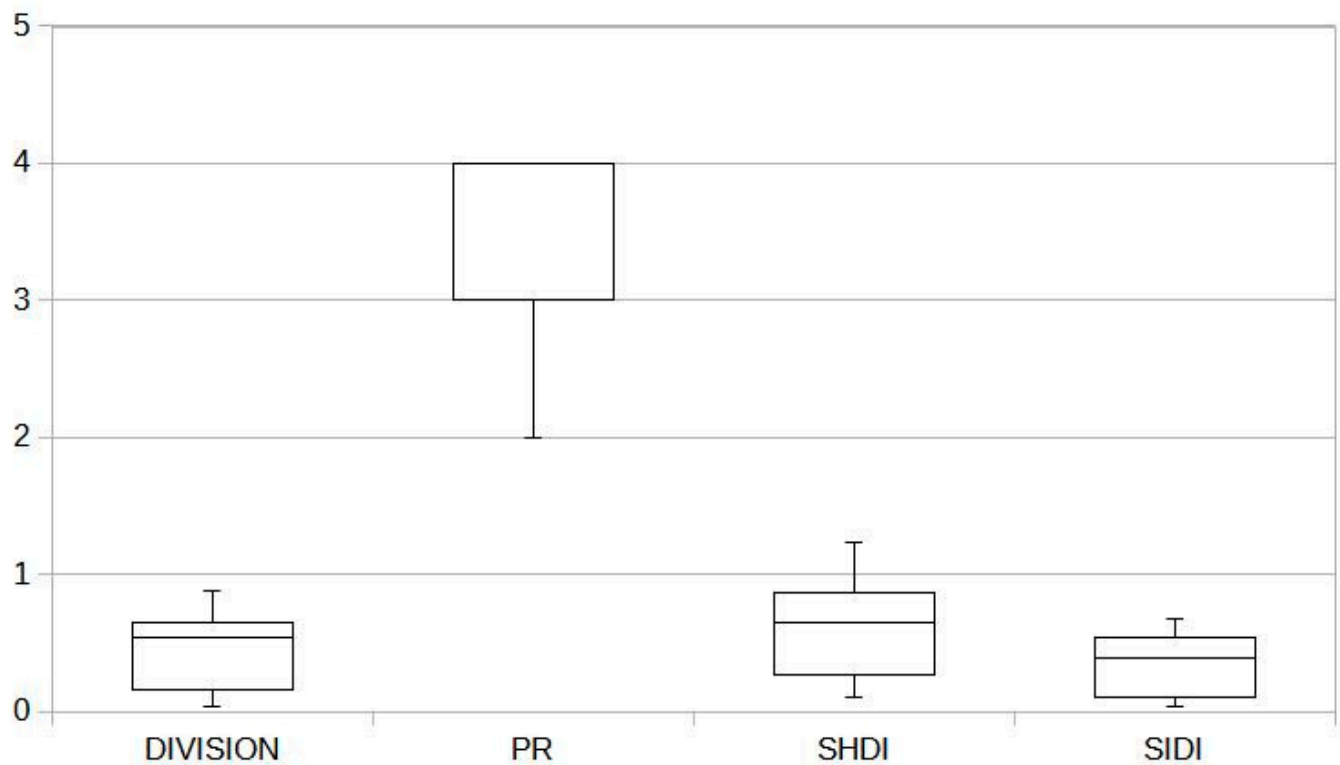

(A)

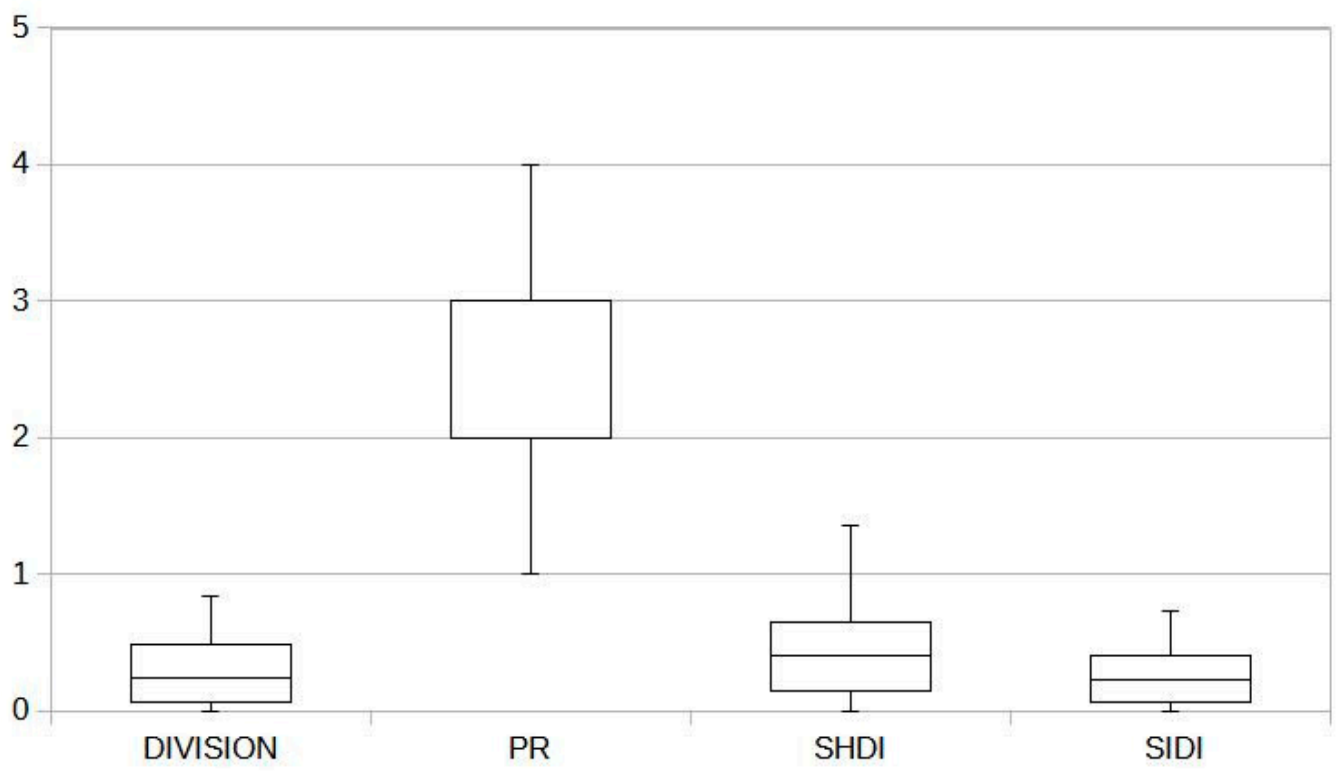

(B)

Figure 5. (A) Measures of landscape differentiation in terms of relief forms: mesoregions. (B) Measures of landscape differentiation in terms of relief forms: microregions.

The greatest discrepancies in the representation of landscape diversity in meso- and microregions due to the dominant type of terrain relief can be observed in the north- 
eastern part of the analyzed area (Figure 4). The mesoregions where this difference is particularly visible include Chodzież Lakeland (six out of 10 microregions have a different type of dominant landscape than the higher-rank unit) and Gniezno Lakeland (five out of 10 microregions represent a different type of dominant landscape).

\subsection{Directions of Landscape Diversity Protection in the Wielkopolskie Voivodeship}

In the Wielkopolskie voivodeship, the areas in which high landscape value is one of the main protection goals include national parks, landscape-type nature reserves, landscape parks, and areas of protected landscape. The mentioned areas belong to the national system of forms under protection and are largely protected as they are part of the Natura 2000 networks. About 30\% of the area of Wielkopolskie voivodeship is protected due to its landscape value. In terms of area, the biggest role in preserving landscape diversity is played by protected landscape areas (78.1\%). In the Wielkopolskie voivodeship there are 38 such objects and they cover the total area of 688,400 ha. According to the legal definition, it is a form of nature protection, covering areas that are valuable due to their distinctive landscape with diverse ecosystems, and important for satisfying needs related to tourism and recreation, or fulfilling functions of ecological corridors. Landscape parks have an important position in terms of number (14 sites) and area (183,100 ha) (Table S1 and Figure 6). These areas are protected because of their natural, historical, and cultural values as well as landscape assets in order to preserve and popularize them under the conditions of sustainable development. Their share in the structure of areas related to the preservation of landscape diversity is over $20 \%$. Due to the lower rigor of protection in landscape parks and protected landscape areas, the effectiveness of measures to safeguard landscape values is insufficient and causes many conflicts, especially in relation to urbanization processes and the level of development of tourist and agricultural functions $[63,66,67]$. National parks (two sites with a total area of 7980 ha) and landscape-type nature reserves (six sites with a total area of 2000 ha) are also important in protecting landscape value in the Wielkopolskie voivodeship. National parks are areas characterized by distinctive natural, scientific, social, cultural, and educational value, with an area of not less than 1000 ha, where the wholenature and landscape values of the areas preserved in their natural or little-changed state are protected. Landscape-type nature reserves are, in turn, areas preserved in a natural or little-changed state, distinguished by specific landscape value. The small number and small total area of these forms of protection are the result of too many restrictions on economic activity and the associated lack of public acceptance of proposals to enlarge existing sites or to create new ones. Their share in the surface landscape protection on the voivodeship scale is $0.9 \%$ for national parks and $0.2 \%$ for landscape-type nature reserves.

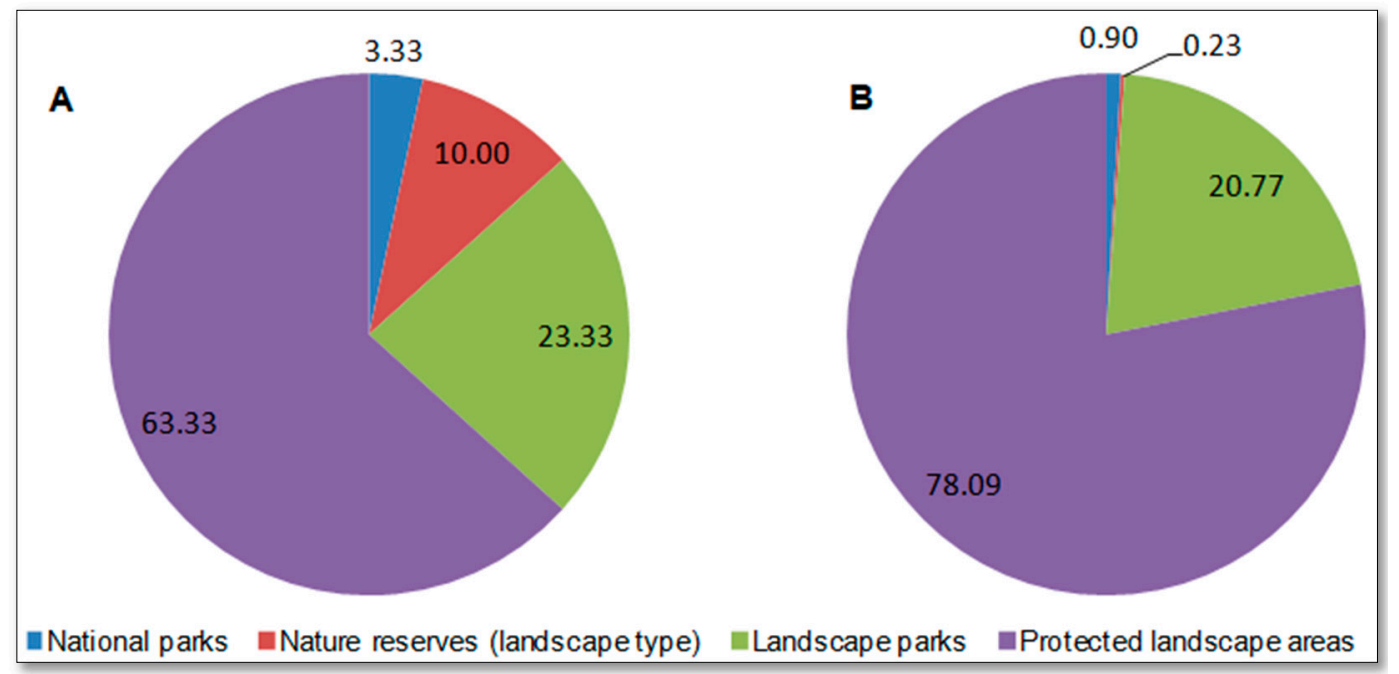

Figure 6. Areas of legal protection of landscape values in the Wielkopolskie voivodeship according to the number of objects (A) and their area (B). 
The analysis showed that, considering the average number of landscape units per particular category of protected areas, the greatest differentiation is found in the areas of protected landscape. The value of this index is 2.39 for mesoregion units, 5.03 for microregion units, and 5.76 for landscape types. Similar values were obtained for landscape parks: 2.29 for mesoregions, 3.57 for microregions, and 6.07 for landscape types. The lowest values were obtained by national parks, where the analyzed index reaches 2 for mesoregions, 3 for microregions, and 2.5 for landscape types (Figures 7A and 8). The highranking position of protected landscape areas results from their large area (the average protected landscape area is $27,500 \mathrm{ha}$, that of a landscape park is $13,100 \mathrm{ha}$, and that of a national park is $9500 \mathrm{ha}$ ); thus, a larger number of units can be included in the range of such an area.

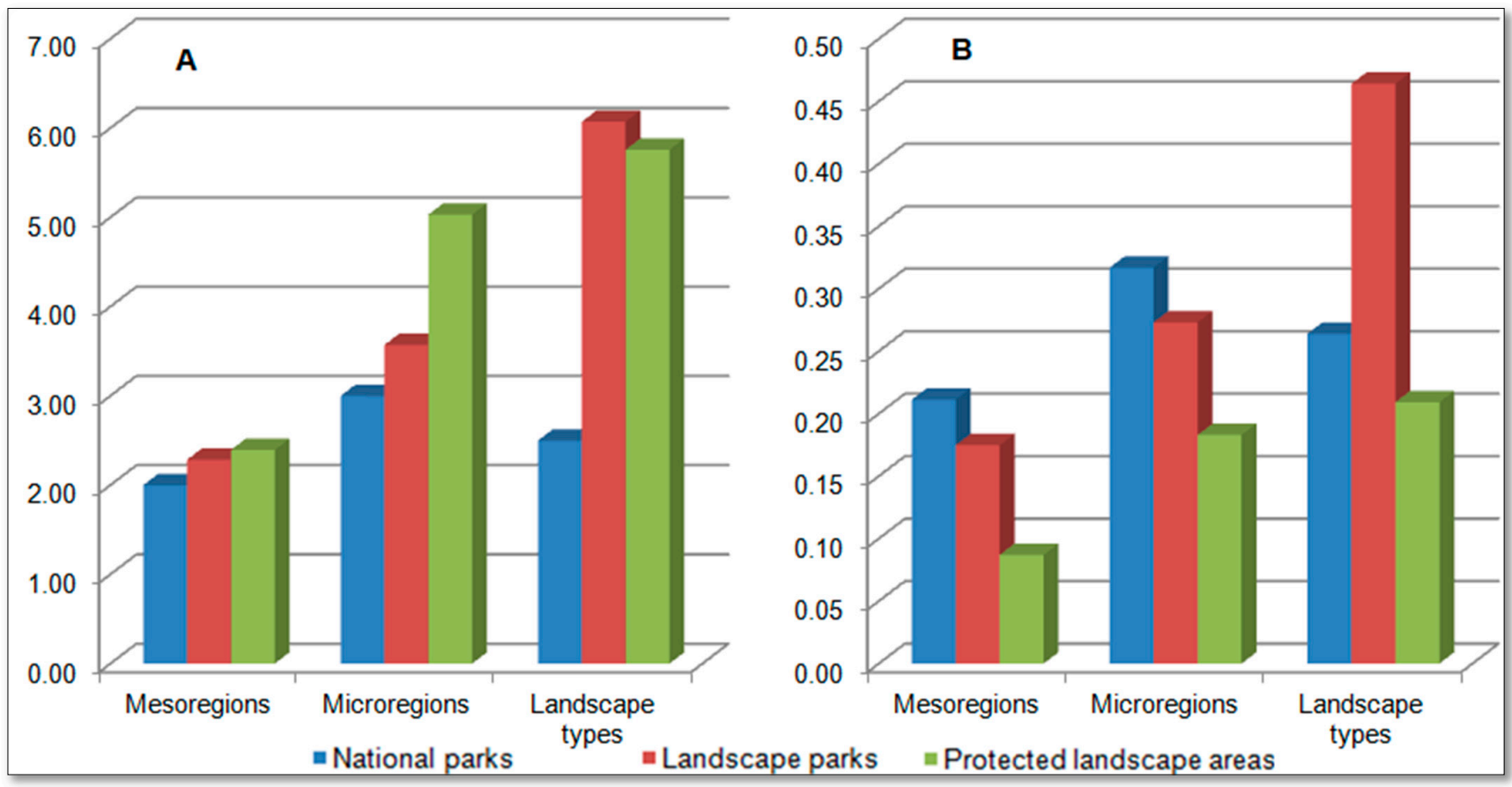

Figure 7. Landscape diversity in different categories of protected areas in the Wielkopolskie voivodeship with consideration of the average number of landscape units [(number of units/protected area (A) and their density (number of units/protected area) (B)].

The landscape diversity of the protected areas is much better illustrated by the second indicator, landscape unit density, i.e., the number of units per 1000 ha of protected area. The index has high values for national parks, where the density of landscape units is the highest for microregions at 0.32 units $/ 1000$ ha, followed by mesoregions at 0.21 units/1000 ha, and 0.26 units $/ 1000$ ha for landscape types. In landscape parks, the density of units is as high as 0.46 units $/ 1000$ ha for landscape types, while for microregions and mesoregions, it is much lower, reaching 0.27 and 0.17 units $/ 1000$ ha, respectively. The lowest values of the landscape unit density index were recorded for protected landscape areas, reaching 0.21 units/1000 ha for landscape types, 0.18 units/1000 ha for microregions, and 0.09 units /1000 ha for mesoregions (Figures 7B and 8). 

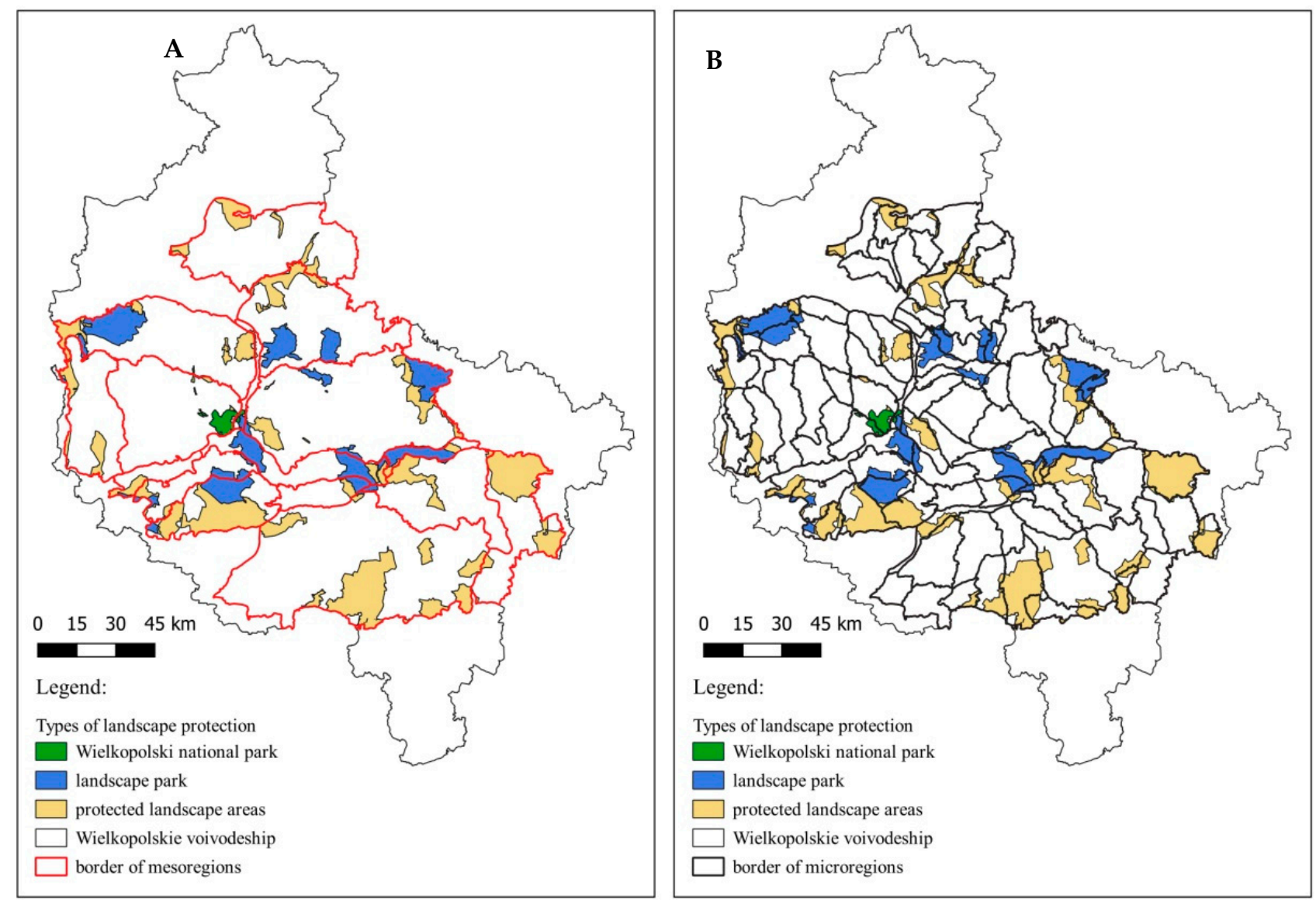

Figure 8. Differentiation of landscape units within the range of protected areas illustrated with an example of the analyzed mesoregions (A) and microregions (B).

The analysis of indicators shows that considering the rank of the protected area and its internal differentiation, the most effective protection of landscape values is achieved by national parks in the case of differentiation into microregions and landscape parks in relation to landscape types. It is a favorable situation given the protection goals, which, in national parks, are aimed at the comprehensive protection of natural values related to both the biotic and abiotic features of the environment. In landscape parks, protection, to a greater extent, considers the physiognomic features of the landscape, which are reflected in the differentiation of typological units.

Protected areas with high landscape diversity in terms of physical and geographical regions and typological units include the Wielkopolski National Park (five microregions and four landscape types) and landscape parks such as Przemęt landscape park (five microregions and 12 landscape types), Sieraków landscape park (six microregions and eight landscape types), Powidz (five microregions and seven landscape types), General Dezydery Chłapowski landscape park (four microregions and eight landscape types), as well as Rogalin and Żerków-Czeszewo landscape parks (five microregions and six landscape types each). Within the areas of protected landscape, a high diversity of units is shown by: Gopło-Kujawy (14 microregions and 12 landscape types), Krzywin-Osieczna with General Dezydery Chłapowski's woodlands and the Osieczna-Góra forest complex (11 microregions and 11 landscape types), the Noteć River Valley (17 microregions and seven landscape types), the Ostrzeszów Hills and Odolanów Valley (eight microregions and 10 landscape types), the Wałcz Lakeland and Gwda River Valley (12 microregions and five landscape types), the Przemęt-Wschowa and Włoszakowice forest complex (six microregions and 10 landscape types), and the Noteć Forest (nine microregions and six landscape types) (Table S1 and Figure 8). 


\section{Conclusions}

The Wielkopolskie voivodeship is a heterogeneous region in terms of natural conditions. This is due to the different geneses of the natural environmental features, in particular the relief, the superficial geological structure, and the soil, which formed under the influence of older and younger glaciations. This affected the nature and intensity of economic processes, which are reflected in the structure of land cover and land use. Recognizing and assessing the spatial variability in landscape is now the basis for taking effective actions to protect it [51,57]. Additionally, landscape research should be more strongly linked to research on landscape policies and planning instruments [72-74]. The methodological solutions adopted and results obtained in this study enable wide and comprehensive approaches to the issue. This is supported by reference to two different divisions of natural space: physical and geographical regionalization and landscape typology, which are treated as standard in Polish landscape research and used in the implementation of landscape audits $[30,35,43]$.

The obtained results indicate the complementary nature of the developed landscape divisions. Regional division (delimitation of microregions) is a mapping of environmental features that enable geo and biodiversity analysis. The typological division, conversely, focuses to a greater extent on the properties resulting from the economic use of the landscape, and, consequently, on its cultural and physiognomic values. The presented methodological approach enables simultaneous use of both classifications in landscape research and allows for an integrated approach to the assessment of landscape structure and function at different levels of its organization. This provides a suitable basis for interdisciplinary research developed at the interface of biology, geography, and landscape science and their practical applications, e.g., in nature conservation, spatial planning, or landscape architecture.

The methodological novelty of this study is the use of ranked microregion units to characterize the diversity of landscape structure for an area as large as a voivodeship. The delimitation of microregions and the analysis of their internal differentiation indicate a high homogeneity of natural environmental features within the boundaries of individual units, which enables their wide use as units of basic assessment in ecophysiographic analyses [52,75]. The second important premise is an accurate representation of the dominant features of land cover and land use in the microregion system and its high compatibility with the spatial variability in this landscape feature observed at the scale of the whole voivodeship. It allows us to conclude that the physical and geographical (microregional) division adequately reflects the relationship between the features of the natural environment and human activity, and thus can be used in studies on the landscape structure of large administrative regions and for planning their sustainable development in ecological and socio-economic dimensions.

The analysis of the spatial structure of the landscape within the boundaries of the areas designated for preservation of landscape values showed that in the Wielkopolskie voivodeship, the areas under protection have relatively high diversity and density of natural units. In relation to physical and geographical microregions, the highest diversity and density of units are found in national parks, while in the case of landscape types, in landscape parks. The described relationship is consistent with the legal status of these areas and the adopted protection objectives, which comprise all natural and physiognomic values of the landscape. The low position of protected landscape areas, from the point of view of the studied features, is confirmed by the selective approach to landscape protection, which focuses on the preservation of tourist value and the role of these areas as ecological connectors.

The proposed patterns of delimiting landscape units (physico-geographical regions and landscape types) and examples of their compilation allow for comprehensive analyses for various research areas, both in Europe and around the world. The developed landscape typology may serve to organize knowledge about the degrees and forms of contemporary landscape transformations and their evolution over time. The physical and geographic regionalization allows the analysis of the relationships between the directions of anthro- 
pogenic landscape use and their natural conditions related to the features of elements such as topography, geological structure, water, and soil. For this reason, physico-geographical regions, especially the rank of microregions, can be used as units for both the inventorying of natural resources and the assessing of the potential of landscapes or the ecosystem services they provide. This approach provides the basis for effective and sustainable landscape policy at the local and supralocal levels.

Supplementary Materials: The following are available online at https:/ /www.mdpi.com/article/10 $.3390 /$ su132413812/s1, Table S1: The characteristic of landscape protection forms.

Author Contributions: Conceptualization, S.B., M.K. and A.M.; methodology, S.B. and M.K.; software, M.K.; validation, M.K.; formal analysis, S.B. and M.K.; data curation, M.K.; writing-original draft preparation, S.B. and M.K.; writing-review and editing, S.B., M.K. and A.M.; visualization, M.K.; supervision, S.B., M.K. and A.M.; project administration, M.K. All authors have read and agreed to the published version of the manuscript.

Funding: This research received no external funding.

Institutional Review Board Statement: Not applicable.

Informed Consent Statement: Not applicable.

Data Availability Statement: Data can be obtained by the corresponding author.

Conflicts of Interest: The authors declare no conflict of interest.

\section{References}

1. Holling, C.S. Understanding the complexity of economic, ecological and social systems. Ecosystems 2001, 4, 390-405. [CrossRef]

2. Folke, C.; Carpenter, S.; Walker, B.; Scheffer, M.; Elmqvist, T.; Gunderson, L.; Holling, C.S. Regime shifts, resilience, and biodiversity in ecosystem management. Annu. Rev. Ecol. Evol. Syst. 2004, 35, 557-581. [CrossRef]

3. Folke, C.; Hahn, T.; Olsson, P.; Norberg, J. Adaptive governance of social-ecological systems. Annu. Rev. Environ. Resour. 2005, 30, 441-473. [CrossRef]

4. Biggs, R.; Schlüter, M.; Biggs, D.; Bohensky, E.L.; Burn Silver, S.; Cundill, G.; Dakos, V.; Daw, T.M.; Evans, L.S.; Kotschy, K.; et al. Toward principles for enhancing the resilience of ecosystem services. Annu. Rev. Environ. Resour. 2012, 37, 421-448. [CrossRef]

5. Sharples, C. Geoconservation in forest management-Principles and procedures. Tasforests 1995, 7, 37-50.

6. Eberhard, R. Pattern and process: Towards a regional approach to national estate assessment of geodiversity. Technical Series No. 2. In Australian Heritage Commission \& Environment Forest Taskforce; Environment Australia: Canberra, Australia, 1997.

7. Gordon, J.E. Geological conservation. In Encyclopedia of Geology; Elsevier: Amsterdam, The Netherlands, 2005 ; pp. 29-35.

8. Richling, A.; Solon, J. Ekologia krajobrazu; Wydawnictwo Naukowe PWN: Warsaw, Poland, 2011.

9. Gray, M. Geodiversity_Valuing and Conserving Abiotic Nature; John Wiley \& Sons: Chichester, UK, 2013.

10. Gray, M. Geodiversity: The backbone of geoheritage and geoconservation geoheritage. In Assessment, Protection, and Management, Chapter 1; Elsevier: Amsterdam, The Netherlands, 2018; pp. 13-26.

11. Zwoliński, Z.; Najwer, A.; Giardino, M. Methods for Assessing Geodiversity, Geoheritage. Assessment, Protection, and Management, Chapter 2; Elsevier: Amsterdam, The Netherlands, 2018; pp. 27-52.

12. Grime, J.P. Biodiversity and ecosystem function: The debate deepens. Science 1997, 277, 1260-1266. [CrossRef]

13. Barthlott, W.; Biedinger, N.; Braun, G.; Feig, F.; Kier, G.; Mutke, J. Terminological and methodological aspects of the mapping and analysis of the global biodiversity. Acta Bot. Fenn. 1999, 162, 103-110.

14. Magurran, A. Measuring Biological Diversity; Blackwell Publishing: Oxford, UK, 2003.

15. Elmqvist, T.; Folke, C.; Nyström, M.; Peterson, G.; Bengtsson, J.; Walker, B.; Norberg, J. Response diversity, ecosystem change, and resilience. Front. Ecol. Environ. 2003, 1, 488-494. [CrossRef]

16. Elmqvist, T.; Matby, E.; Barker, T.; Mortimer, M.; Perrings, C.; Aronson, J. Biodiversity, ecosystems and ecosystem services. In The Economics of Ecosystems and Biodiversity: Ecological and Economic Foundations; Kumar, P., Ed.; Earthscan: London, UK, 2010; pp. $1-96$.

17. Norris, K.; Terry, A.; Hansford, J.P.; Turvey, S.T. Biodiversity conservation and the earth system: Mind the gap. Trends Ecol. Evol. 2020, 35, 919-926. [CrossRef]

18. Frankel, O.H.; Soule, M.E. Conservation and Evolution; Cambridge University Press: Cambridge, UK, 1981.

19. Takacs, D. The Idea of Biodiversity: Philosophies of Paradise; The Johns Hopkins University Press: Baltimore, MD, USA, 1996.

20. Callicott, J.B.; Crowder, L.B.; Mumford, K. Current normative concepts in conservation. Conserv. Biol. 1999, 13, 22-35. [CrossRef]

21. Duelli, P.; Obrist, M.K. Biodiversity indicators: The choice of values and measures. Agric. Ecosyst. Environ. 2003, 98, 87-98. [CrossRef] 
22. Sarkar, S. Biodiversity and Environmental Philosophy: An Introduction, Cambridge Studies in Philosophy and Biology; Cambridge University Press: New York, NY, USA, 2005.

23. Tilman, D. The ecological consequences of changes in biodiversity: A search for general principles. Ecology 1999, 80, 1455-1474. [CrossRef]

24. McCann, K.S. The diversity-stability debate. Nature 2000, 405, 228-233. [CrossRef] [PubMed]

25. Naumann, C.M. Biodiversity-Is there a second chance? In Biodiversity; Barthlott, W., Winiger, M., Biedinger, N., Eds.; Springer: Berlin/Heidelberg, Germany, 2001; pp. 3-11.

26. Naeem, S. Ecosystem consequences of biodiversity loss: The evolution of a paradigm. Ecology 2002, 83, 1537-1552. [CrossRef]

27. Pollock, L.J.; O'Connor, L.M.J.; Mokany, K.; Rosauer, D.F.; Talluto, M.V.; Thuiller, W. Protecting biodiversity (in All Its Complexity): New models and methods. Trends Ecol. Evol. 2020, 35, 1119-1128. [CrossRef]

28. Schulze, E.D.; Gerstberger, P. Functional aspects of landscape diversity: A Bavarian example. In Biodiversity and Ecosystem Function; Schulze, E.D., Mooney, H.A., Eds.; Springer: Berlin/Heidelberg, Germany, 1993.

29. Leserl, H.; Nagee, P. Landscape diversity-A holistic approach. In Biodiversity. A Challenge for Development Research and Policy; Springer: Berlin/Heidelberg, Germany, 2001; pp. 129-143.

30. Bródka, S. Badania Jakościowe w Regionalistyce; Konieczka-Śliwińska, D., Miedzińska, I., Eds.; Instytut Historii UAM: Poznań, Poland, 2016; pp. 121-134.

31. Kondracki, J. W sprawie terminologii i taksonomii jednostek regionalnych w geografii fizycznej Polski. Przeglad Geogr. 1961, 33, 23-38.

32. Kondracki, J. Geografia Fizyczna Polski; Wydawnictwo Naukowe PWN: Warsaw, Poland, 1965.

33. Kondracki, J. Geografia Polski. Mezoregiony Fizycznogeograficzne; Wydawnictwo Naukowe PWN: Warsaw, Poland, 1994.

34. Kondracki, J. Geografia Regionalna Polski; Wydawnictwo Naukowe PWN: Warsaw, Poland, 2000.

35. Solon, J.; Borzykowski, J.; Bidłasik, M.; Richling, A.; Badora, K.; Balon, J.; Brzezińska-Wójcik, T.; Chabudziński, Ł.; Dobrowolski, R.; Grzegorczyk, I.; et al. Physico-Geographical Mesoregions of Poland: Verification and Adjustment of Boundaries on the Basis of Contemporary Spatial Data. Geogr. Pol. 2018, 91, 143-170. [CrossRef]

36. Ziaja, W. Fizycznogeograficzne regiony województwa podkarpackiego. Folia. Geo-Graph. Ser. Geogr. Oeconomica 2009, 33, 13-28.

37. Balon, J.; Jodłowski, M.; Krąż, P. The Tatra Mountains: Physico-geographical regions. In Atlas of the Tatra Mountains: Abiotic nature, Zakopane: Tatra National Park, Plate I.4; Dąbrowska, K., Guzik, M., Eds.; Wyd. Tatrzańskiego Parku Narodowego: Zakopane, Polska, 2015.

38. Migoń, P.; Kasprzak, M. Regiony fizyczno-geograficzne. In Przyroda Dolnego Ślaska, Wydanie 2; Żelaźniewicz, A., Ed.; Oddział Polskiej Akademii Nauk we Wrocławiu: Wrocław, Poland, 2015; pp. 19-36.

39. Nita, J.; Myga-Piątek, U.; Pukowiec-Kurda, K. Propozycja mikroregionalizacji województwa śląskiego-Weryfikacja metody na wybranych mezoregionach. Pr. Kom. Kraj. Kult. 2016, 31, 43-56.

40. Kot, R. Propozycja weryfikacji regionalizacji fizycznogeograficznej Polski na przykładzie wybranych regionów Niżu Polskiego. Probl. Ekol. Kraj. 2011, 29, 29-39.

41. Kot, R. Mikroregiony fizycznogeograficzne. In Atlas Województwa Kujawsko-Pomorskiego; Kozieł, Z., Ed.; Wydawnictwo Uniwersytetu Mikołaja Kopernika: Toruń, Poland, 2015; pp. 60-61.

42. Kistowski, M.; Szydłowski, J. Problemy Regionalizacji Fizycznogeograficznej Terenów Młodoglacjalnych i Nadmorskich Pomorza w Świetle Dotychczasowej Ewolucji Pogląów i Wykonanych Podziatów; Prace Geograficzne, Instytut Geografii i Przestrzennego Zagospodarowania PAN: Warsaw, Poland, 2018; Volume 266, pp. 43-66.

43. Macias, A.; Bródka, S.; Kubacka, M.; Piniarski, W. Physical and Geographical Regionalization and Environmental Management: A Case Study in Poland. Pol. J. Environ. Stud. 2020, 29, 1-10. [CrossRef]

44. Ostaszewska, K. Geografia Krajobrazu; Wydawnictwo Naukowe PWN: Warsaw, Poland, 2002.

45. Solon, J. Przegląd wybranych podejść do typologii krajobrazu. Probl. Ekol. Kraj. 2008, 20, 25-33.

46. Solon, J. Wybrane Podejścia do Typologii Krajobrazu w Polsce i ich Przydatność dla Implementacji Europejskiej Konwencji Krajobrazowej. Identyfikacja i Waloryzacja Krajobrazów_Wdrażanie Europejskiej Konwencji Krajobrazowej; GDOŚ: Warsaw, Poland, 2013 ; pp. 17-25.

47. Degórski, M. Krajobraz jako odbicie przyrodniczych i antropogenicznych procesów zachodzacych w megasystemie środowiska geograficznego. Probl. Ekol. Kraj. 2009, 23, 53-60.

48. Chmielewski, T.J. Systemy Krajobrazowe. Struktura-Funkcjonowanie-Planowanie; Wydawnictwo Naukowe PWN: Warsaw, Poland, 2012.

49. Chmielewski, T.J.; Kułak, A. Struktura fizjonomiczna krajobrazu. In Struktura Środowiska Przyrodniczego a Fizjonomia Krajobrazu. Struktura Środowiska Przyrodniczego a Fizjonomia Krajobrazu; Ziaja, W., Jodłowski, M., Eds.; Instytut Geografi i i Gospodarki Przestrzennej, Uniwersytet Jagielloński: Kraków, Poland, 2014; pp. 33-52.

50. Myga-Piątek, U. Mapa krajobrazów kulturowych tradycja-potrzeby—trudności-próby-możliwości. Pr. Kom. Kraj. Kult. PTG 2015, 27, 2-30.

51. Chmielewski, T.J.; Myga-Piątek, U.; Solon, J. Typologia aktualnych krajobrazów. Pol. Przegląd Geogr. 2015, 87, 377-408. [CrossRef]

52. Macias, A.; Bródka, S. Nature (abiotic and biotic) features and objects-Distinguishing features of landscape identity. Probl. Landsc. Ecol. 2015, 40, 187-198.

53. Richling, A.; Dąbrowski, A. Mapa typów krajobrazów naturalnych Polski, plansza 53.1. In Atlas Rzeczypospolitej Polskiej, Główny Geodeta Kraju; IGiPZ PAN, PPWK im. E. Romera: Warsaw, Poland, 1995. 
54. Richling, A.; Ostaszewska, K. Geografia Fizyczna Polski; Wydawnictwo Naukowe PWN: Warsaw, Poland, 2005.

55. Badora, K. Stan Środowiska Przyrodniczego a Klasyfikacje Krajobrazów. Probl. Ekol. Kraj. 2008, 20, $219-224$.

56. Solon, J. Typy Krajobrazu Kulturowego Polski. Probl. Ekol. Kraj. 2008, 20, 109-115.

57. Solon, J. Krajobraz jako przestrzeń integrująca różne podejścia do ochrony dziedzictwa przyrodniczego i kulturowego oraz kształtowania warunków życia społeczeństwa. In Społeczny Wymiar Krajobrazu Kulturowo-Przyrodniczego; Ratajski, S., Ed.; Polski Komitet do spraw UNESCO: Warsaw, Poland, 2015; pp. 27-47.

58. Śleszyński, P.; Solon, J. A map of the landscape diversity of Poland. Geogr. Pol. 2017, 90, 369-377. [CrossRef]

59. Chmielewski, T.J.; Śleszyński, P.; Chmielewski, S.; Kułak, A. Główne Kierunki Zmian Zachodzacych w Krajobrazowych Systemach Ekologicznych Polski i Próba Oceny ich Skutków; Prace Geograficzne; Instytut Geografii i Przestrzennego Zagospodarowania PAN: Warsaw, Poland, 2018; p. 264.

60. McGarigal, K.; Cushman, S.A.; Ene, E. FRAGSTATS v4: Spatial Pattern Analysis Program for Categorical and Continuous Maps. Computer software program produced by the authors at the University of Massachusetts, Amherst. 2012. Available online: http:/ / www.umass.edu/landeco/research/fragstats/fragstats.html (accessed on 8 December 2021).

61. McGarigal, K.; Cusham, S.A. Comparative evaluation of experimental approaches to study of habitat fragmentation effects. Ecol. Appl. 2002, 12, 335-345. [CrossRef]

62. Kubacka, M.; Smaga, Ł. Effectiveness of Natura 2000 areas for environmental protection in 21 European countries. Reg. Environ. Chang. 2019, 19, 2079-2088. [CrossRef]

63. Kubacka, M. Evaluation of the ecological efficiency of landscape protection in areas of different protection status. A case study from Poland. Landsc. Res. 2019, 44, 628-641. [CrossRef]

64. Plexida, S.G.; Sfougaris, A.I.; Ispikoudis, I.P.; Papanastasis, V.P. Selecting landscape metrics as indicators of spatial heterogeneityA comparison among Greek landscape. Int. J. Appl. Earth Obs. Geoinf. 2014, 26, 26-35. [CrossRef]

65. MacLean, M.G.; Congalton, R.G. A comparison of landscape fragmentation analysis programs for identifying possible invasive plant species locations in forest edge. Landsc. Ecol. 2015, 30, 1241-1256. [CrossRef]

66. Kubacka, M.; Macias, A. The functioning of Natura 2000 Areas in the opinion of different groups from the local community: A case study from Poland. Soc. Nat. Resour. 2016, 29, 1186-1197. [CrossRef]

67. Singh, S.; Basommi, B.; Mustak, S.; Srivastava, P.; Szabo, S. Modelling of land use land cover change using earth observation data—sets of Tons River Basin, Madhya Pradesh, India. Geocarto Int. 2018, 33, 1202-1222. [CrossRef]

68. McGarigal, K.; Marks, B.J. Fragstats: Spatial Pattern Analysis Program for Quantifying Landscape Structure; US Department of Agriculture, Forest Service, Pacific Northwest Research Station: Corvallis, OR, USA, 1995; p. 61.

69. Comer, D.; Greene, J.S. The development and application of a land use diversity index for Oklahoma City, OK. Appl. Geogr. 2015, 60, 46-57. [CrossRef]

70. Neill, R.V.; Hunsaker, C.T.; Timmins, S.P.; Jackson, B.L.; Jones, K.B.; Ritters, K.H.; Wickham, J.D. Scale problems in reporting landscape pattern at the regional scale. Landsc. Ecol. 1996, 11, 169-180. [CrossRef]

71. Yue, D.; Guo, J.; Hui, C. Scale dependency of biocapacity and the fallacy of unsustainable development. J. Environ. Manag. 2013, 126, 13-19. [CrossRef]

72. Conrad, E.; Christie, M.; Fazey, I. In research keeping up with changes in landscape policy? A review of the literature. J. Environ. Manag. 2011, 92, 2097-2108. [CrossRef]

73. Hersperger, A.M.; Bürgi, M.; Wende, W.; Bacău, S.; Grădinaru, S.M. Does landscape play a role in strategic spatial planning of European urban regions? Landsc. Urban Plann. 2020, 194, 103702. [CrossRef]

74. Wende, W.; Walz, U.; Stein, C. Evaluating municipal landscape plans and their influence on selected aspects of landscape development-An empirical study from Germany. Land Use Policy 2020, 99, 104855. [CrossRef]

75. Bródka, S.; Macias, A. Environmental studies and maps in spatial planning at the regional level in Poland. Quaest. Geogr. 2008, 27, 19-30. 